\title{
Růst turistické atraktivity obcí v Beskydech: Př́padová studie horské obce Bílá, Česko
}

\author{
Jan HAVRLANT \\ Growth of Tourist Attractiveness of Municipalities in the Beskydy Mountains: Case Study \\ of the Bíla Mountain Village, Czechia
}

Abstract: The article assesses the changes in the tourist attractiveness of a mountain village in the border area of the Beskydy Mountains in relation to the development of tourism. The objective is to identify the impacts of tourism in the region of interest based on analyses of tourist infrastructure, innovations of the holiday resort portfolios, and development of new services in the municipality of Bílá, where a series of development projects focusing on tourism has been implemented in the past few years. The methods of questionnaire surveys and interviews with municipality representatives and other key local stakeholders were used to assess the social and economic contributions of tourism and other effects of the increased number of resort visitors for the municipality. The substantial investments into tourism infrastructure innovations have brought a lot of positive effects to the municipality. Some of the key effects include significant increase in job opportunities, positive demographic changes etc. The character of the municipality, which used to be peripheral with migration loss of population, has changed in the last decade as a result of the triple increase in the number of visitors and tourism intensity. The number of jobs in Bíla has increased, particularly in various fields of services related to tourism, which led to increase in commuting to Bílá. Tourism has increased revenues to the municipal budget by eighty times in the last two decades, coming from the fees for recreational stays and accommodation fees, as well as from the lease of real estate. The municipality has substantially changed its image in relation to the dynamic development of tourism and investments into sports and leisure infrastructure, as well as to the development of various events and other activities. Also, Bílá is becoming attractive in relation to business opportunities and is one of the unique mountain villages with a significant potential for development within the peripheral border regions of the Czech Republic.

Keywords: attractiveness of the village, Beskydy Mountains, Bílá, Czechia, tourism

\section{Úvod}

Oblast Beskyd, jako součást turistického regionu Severní Moravy a Slezska, disponuje jedinečnými podmínkami k rozvoji horské turistiky, rekreace, zimních sportů a dalších volnočasových aktivit. Ačkoliv se některé beskydské venkovské obce vyprofilovaly v průběhu minulého století jako obce rekreační, na většině území byl jejich turistický potenciál, zvláště ve formách volného cestovního ruchu, jen omezeně využíván. Jejich rozvoj až do konce 80 . let 20. století více méně stagnoval. Pro horské regiony s převahou obcí venkovského typu byl ve 2. polovině 20. století v etapě socialistického vývoje př́značný nepříznivý demografický, migrační i sociálněekonomický vývoj, doprovázený hospodářským zaostáváním, typickým zejména pro periferní regiony. K nim náleží i př́hraniční část Beskyd s obcemi Bílá, Staré Hamry, Krásná, Horní a Dolní Lomná, Velké Karlovice aj. K dynamickému lokálnímu rozvoji a růstu turistické atraktivity některých obcí došlo až v posledních 20 letech v souvislosti se značnými

DOI: https://doi.org/10.33542/GC2020-1-02 
investicemi do modernizace turistické a sportovně-rekreační infrastruktury. Obec Bílá, ležící v pohoři Moravskoslezských Beskyd $(550$ - 950 m n. m.) při hranici se Slovenskem, má v rámci Česka výrazně periferní polohu. Obec se dlouhodobě potýkala se všemi problémy typickými pro periférie. Ve svém historickém vývoji byla provázena pohnutým děním, at' už při osídlování horského území v minulých staletích, tak v první polovině 20. století v době válečných událostí i později, v etapě socialistického vývoje, kdy venkovské obce v Beskydech byly zařazeny do kategorie nestřediskových obcí, bez preferencí intenzivnějšího sídelního a hospodářského rozvoje. Z hlediska lokálního rozvoje měla v první polovině 20. století značný význam výstavba železnice z Frýdlantu nad Ostravicí do Starých Hamer a Bílé. Trat' spojila v roce 1910 průmyslovou oblast Ostravska s Beskydami a umožnila mj. rozvoj horské turistiky. Významnou změnou byla v 60. letech výstavba přehrady Šance na toku Ostravice v katastru sousední obce Staré Hamry. V této souvislosti byla v roce 1965 železnice z Ostravice do Bílé zrušena. Nad vodárenskou nádrží byla vybudována silnice I/56, dodnes klíčová komunikace z hlediska spojení ostravské konurbace s oblastí Beskyd. Rekreační potenciál horského území byl ve druhé polovině 20. století využíván především ve formách vázané podnikové rekreace a individuální rekreace v objektech druhého bydlení (Havrlant 1977). Omezené využití potenciálu venkovských obcí bylo a je dáno také skutečností, že zájmové území je součástí chráněné krajinné oblasti Beskydy, v níž jsou veškeré hospodářské aktivity důsledně regulovány. Lesy, jako jeden z fenoménů CHKO, zaujímají přes 90 \% rozlohy zájmového území. V rámci Česka patří k nejrozsáhlejším lesním komplexům. Přesto má v obci cestovní ruch a rekreace $\mathrm{v}$ posledních dvaceti letech rostoucí význam. Cílem článku je zhodnotit změny turistické atraktivity venkovských obcí v oblasti Beskyd po společenských změnách a pádu totalitního systému, kdy v této horské oblasti došlo $\mathrm{k}$ rozsáhlé transformaci dřívějších rekreačních středisek a k rozvoji nové turistické infrastruktury a nových služeb. Záměrem př́ípadové studie v obci Bílá bylo zhodnotit rozvoj volného cestovního ruchu a rovněž analyzovat socioekonomické dopady rozvoje turismu ve specifickém příhraničním území.

\section{Teoretická východiska a metodika výzkumu}

Turistická atraktivita regionů, měst a obcí bývá do značné míry ovlivněna vhodnými lokalizačními, realizačními a selektivními předpoklady cestovního ruchu. Cestovní ruch se stal fenoménem současnosti a důležitou součástí hospodářství většiny vyspělých zemí. Může být významným nástrojem regionálního a lokálního rozvoje a iniciátorem rozvoje podnikatelských aktivit, jakož i revitalizace hospodářsky zaostávajících venkovských, periferních nebo strukturálně postižených regionů, pokud mají tyto regiony co nabídnout a zároveň existuje-li zájem o tuto nabídku (Vystoupil, Šauer 2006). Cestovní ruch bývá také chápán jako jeden z důležitých stabilizačních faktorů ve vztahu k místnímu obyvatelstvu a sociálně-kulturnímu zázemí. Z hlediska socioekonomického generuje nové trvalé i sezónní pracovní př́ležitosti ve službách cestovního ruchu, ale také finanční zdroje a další přínosy. Proto je mnohdy vnímán jako zachránce v lokálním rozvoji a může se stát klíčovým v procesu rozšiřrení a diferenciace lokálních hospodářství (většinou se jedná o malé a středně velké subjekty). Pro jeho rozvoj je však nezbytná turistická infrastruktura a systém souvisejících služeb (ubytovacích, stravovacích, dopravních, informačních, služeb rekreačních a kulturně-společenských zařízení, služeb cestovních kanceláríi, průvodců a řady dalších doplňkových služeb soukromého i veřejného sektoru) (Horner, Swarbrooke, 2003). Cestovní ruch vyvolává řadu přímých i nepř́mých dopadů a efektů. Jeho ekonomické prínosy se projevují v podílu na tvorbě HDP, na daňových a devizových př́ijmech do státních, regionálních a místních rozpočtu (Kalabisová, Studnička, Plzáková, Tinková 2012). Cestovní ruch nejen propojuje řadu odvětví nevýrobního sektoru, ale nepřímo ovlivňuje i výrobní odvětví, rozvoj zpracovatelského a stavebního průmyslu, rozvoj dopravní a technické infrastruktury i další investiční aktivity. Jeho vlivy se současně projevují v prolínání tradic, kultur a mají rovněž dopad a tvorbu nové kulturní krajiny. Tyto multiplikační efekty cestovního ruchu by však nebyly možné bez koordinace a kooperace soukromého 
a veřejného sektoru. Samosprávy, zejména pak starostové patří po společenských změnách na přelomu 80. a 90. let k aktivním hybatelům rozvoje turismu ve venkovských oblastech (Kalabisová, Studnička, Plzáková, Tinková 2012). Místní samospráva, jako důležitý rozvojový aktér, má významný potenciál ovlivňovat rozvoj obcí. Svými aktivitami ovlivňuje podobu lokalit, může mobilizovat lokální rozvojové zdroje a podílet se na vytváření podmínek pro zlepšování kvality života rezidentů. Vliv samosprávy v malých horských obcích je zásadní z hlediska implementace rozvojových projektů; naproti tomu participace místních občanů na plánování lokálního rozvoje a tvorbě rozvojových strategií bývá ve většině venkovských obcí minimální (Bernard, Kostelecký, Illner, Vobecká 2011), což potvrdily také studie v horských regionech Krkonoš, Šumavy aj. (Horáková, Fialová 2014). Potenciál cestovního ruchu se stále častěji stává součástí rozvojových strategií místních samospráv. Jejich role se v posledních letech mění; je orientovaná více ,podnikatelsky“ a často hledá nové investiční podněty a rozvojové př́ležitosti (Hall, Jenkins, 1995, Mika, Pawlusiński 2003, Pietrzyk Sokulska 2006). Proměna venkovského prostoru prostřednictvím turismu, jako faktoru regionálního a lokálního rozvoje, je určována také změnami v trávení volného času a dynamikou nových forem mobility (George, Mair, Reid 2009). Z hlediska socioekonomického měly tyto změny dopad zejména na venkovské obce, které ve snaze zastavit celkový úpadek, nahrazují propad tradičních forem obživy, dříve s dominantním zemědělstvím nebo lesním hospodářstvím, sektorem nevýrobním (Kurek 2004). Tento postupný přechod od primárního k terciérnímu sektoru je označován za tzv. postproduktivistickou tranzici a vede ke vzniku moderní postindustriální rurality, jež poskytuje nové možnosti využití venkovského prostoru, včetně nových druhů pracovních příležitostí, zvláště ve službách cestovního ruchu (Ilbery 1998). Obce s turistickým potenciálem se v posledních letech stávají místem utváření nových vztahů mezi venkovem a městem a nových obousměrných migrací. V Česku, po rozsáhlé transformaci početných zařízení vázaného cestovního ruchu a objektů druhého bydlení se v horských rekreačních oblastech turismus postupně stal integrální součástí venkovských ekonomik (Horáková, Fialová, 2014).

$\mathrm{K}$ hodnocení venkovských obcí, jejich funkcí a změn turistické atraktivity lze přistupovat $\mathrm{z}$ různých úhlů pohledu. $\mathrm{Z}$ hlediska typologie českého venkovského prostoru byly využity $\mathrm{k}$ charakteristice zájmového území teoreticko-metodologické přístupy Perlína, Kučery a Kučerové (2010) a práce Horákové a Fialové (2014). K hodnocení turistické atraktivity území, obcí či středisek existují taktéž různé přístupy. Atraktivitu lokality nelze vyjádřit jedním univerzálním vzorcem. Již od 70. let minulého století jsou použivány více méně podobné metody hodnocení; od jednoduchých subjektivních posouzení vybraných ukazatelů, nap̌r. návštěvnosti různých zařízení, objektů či eventů, přes ukazatele intenzity turistického ruchu a rekreační funkce (Havrlant 1977, Mariot 1983, Fialová 2014) či modifikovaná verze index turistické funkce (Pásková, Zelenka 2002, Ruda 2008) nebo ukazatel atraktivity destinace (Vaníček 2006) aj. V př́padové studii bylo použito hodnocení turistické atraktivity obce podle metodiky prezentované Páskovou, Zelenkou (2002) především proto, že bylo možné v zájmovém území zhodnotit s využitím komparace vývoj indikátoru turistické funkce obce, resp. intenzity turistického ruchu (Havrlant 1977), za čtyři dekády, od počátku jeho masového rozvoje. Index turistické funkce (ITF = LK/O) dokládá možné využití potenciálu obcí ve vícedenním cestovním ruchu (s přenocováním). Vyjadřuje podíl stálých lůžkových kapacit (LK) v ubytovacích zařízeních volného cestovního ruchu (respektive počet potenciálních turistů, ubytovaných v obci), k počtu trvale bydlících místních obyvatel $(\mathrm{O})$. Tento ukazatel patří mezi klíčové indikátory vývoje vzájemného vztahu rezidentů a turistů a využívá se pro posouzení významu a intenzity cestovního ruchu v dané destinaci (Pásková, Zelenka 2002). Atraktivitu destinace podle metodiky Vaníčka (2006) nebylo možno analyzovat vzhledem $\mathrm{k}$ absenci bližších informací o trvalém bydlišti turistů, kteří do destinace Beskyd přijeli. S touto analýzou je počítáno $\mathrm{v}$ další studii, která bude v zájmovém území zahrnovat i dotazníková šetření mezi turisty s jejich bližší charakteristikou.

Nezbytný terénní výzkum byl zaměřen na inventarizaci veškeré ubytovací, gastronomické, sportovní, rekreační, relaxační a další doprovodné turistické infrastruktury v obci i na rozvoj 
doplňkových služeb ski areálů, bike parku, servisů a půjčoven sportovního vybavení, wellness centra, dětských hřišt' a dalších atrakcí. Dále byly hodnoceny př́nosy turismu v obci na základě vývoje prŕjmů z cestovního ruchu do rozpočtu obce. Rovněž byly analyzovány aktivity obce v rozvoji cestovního ruchu. $Z$ dostupných zdrojů byla $\mathrm{k}$ dispozici některá socioekonomická a demografická data, včetně počtu ekonomicky aktivních osob obce. Za poslední roky bylo možné analyzovat údaje o výši poplatků z vícedenních pobytů turistů a poplatků z ubytovacích kapacit v obci (s vědomím určitých nepřesností ve vykazování počtu ubytovaných hostů, zejména $\mathrm{v}$ rodinných domech a rekreačních objektech druhého bydlení). Z rozpočtů obce byly dále analyzovány položky o pronájmech pozemků v majetku obce pro účely jejich turistického a sportovně-rekreačního využití. Součástí výzkumu byla analýza pracovních příležitostí a vývoje zaměstnanosti v obci. Vzhledem $\mathrm{k}$ nedostatku dalších relevantních statistických dat k hodnocení změn atraktivity obce bylo zapotřebí využít rovněž metod kvalitativního výzkumu. Polostrukturovanými a individuálními rozhovory či dotazníkovým šetřením s klíčovými lokálními aktéry byly získány potřebné informace o aktivitách obce, rekreačních středisek i dalších subjektů. V rámci př́ípadové studie bylo v obci provedeno cca 17 rozhovorů, a to se starostou a dalšími zastupiteli obce, s provozovateli sportovních a rekreačních areálů, s provozovateli lyžařské školy, servisů a wellness centra, s majiteli a vedoucími ubytovacích, gastronomických a dalších zařízení, s dopravci a dalšími poskytovateli doprovodných služeb. Změny turistické atraktivity obce po modernizaci rekreačních středisek, sportovních areálů a inovacích jejich produktové nabídky jsou doloženy analýzou jejich návštěvnosti, zhodnocením využití ubytovacích kapacit hotelových zařízení během roku a indikátorem vývoje turistické funkce obce. Současně byly posouzeny vedle pozitivních i některé vybrané negativní dopady cestovního ruchu v obci, spojené s rozvojem její turistické funkce.

\section{Rozvoj cestovního ruchu a rekreace v Beskydech}

Počátky rozvoje cestovního ruchu v oblasti Beskyd sahají do druhé poloviny 19. století. Avšak masový rozvoj rekreačních středisek zde začal až v 60. letech minulého století. Beskydy se staly významným rekreačním zázemím měst ostravské a zlínské aglomerace. Podle Rajonizace cestovního ruchu ČR (Vystoupil, Holešinská, Kunc et al. 2006) figuruje oblast BeskydValašska mezi pěti nejvýznamnějšími turistickými oblastmi Česka. Budování rekreační infrastruktury zde probíhalo zvláště v 60. a 70. letech, a to v souvislosti s rozvojem početných zařízení vázaného cestovního ruchu (objekty podnikové a odborářské rekreace). Do konce 80. let tak vzniklo v horské oblasti více než 40 rekreačních středisek (Havrlant 2006). V tomto období zejména domácí rekreanti využívali poměrně skromně vybavená sezónní rekreační stř̌ediska. Značnou část návštěvníků Beskyd tvořili také majitelé objektů druhého bydlení rekreačních chat a chalup, které byly využívány k individuální rodinné rekreaci. V oblasti Beskyd (zvláště na území okresu Frýdek-Místek) bylo v průběhu 60. - 80. let postaveno přes 11 tisíc těchto objektů. V obci Bílá bylo koncem 70. let registrováno cca 80 rekreačních chat a chalup s ubytovací kapacitou kolem 440 lůžek (Havrlant 1977). Výrazně vyšší koncentraci chatové zástavby měly obce na úpatí Moravskoslezských Beskyd v dobře dostupných osadách Ostravice (přes 1200 chat), Frýdlantu, Kunčic, Čeladné, Morávky, Dolní Lomné a Malenovic. Chaty a rekreační chalupy v oblasti Beskyd disponují ubytovací kapacitou, dosahující téměř 60 tisíc míst (chaty zde tvoří přes $90 \%$ všech rekreačních objektů). Rekreanty zde byli převážně obyvatelé z ostravské konurbace (Havrlant 2006). Masový rozvoj cestovního ruchu $\mathrm{v}$ některých horských obcích podpořila $\mathrm{v}$ minulém století nově budovaná infrastruktura, zaměřená na lyžařské sporty a turistiku. Kromě lyžařských vleků byla v Beskydech postavena první sedačková lanovka z Trojanovic na Pustevny (v roce 1940); druhá pak z Oldřichovic u Třince na Javorový vrch (v roce 1956) a v 60. letech další z Dolní Lomné na Malý Polom. V období socialistického vývoje však byla v rozvoji turistické infrastruktury preferována zejména střediska vázané rekreace. Naproti tomu střediska pro volný cestovní ruch se rozvíjela 
jen v malé míře, např́íklad v Ostravici, Rožnově pod Radhoštěm a na Pustevnách. Teprve koncem 90. let došlo v několika beskydských lokalitách k modernizaci některých středisek (Rucki 2011). Od roku 2005 probíhala výraznější inovace sportovně-rekreačních zařízení, zvláště v lokalitách Bílé a Kohútky, kde byly nahrazeny staré vleky pohodlnými sedačkovými lanovkami. Současně byly v lyžařských areálech budovány nové zasněžovací systémy, které prodloužily zimní sezónu a umožnily jejich využití i v teplejších sezónách, bez dostatečné př́rodní sněhové pokrývky. $\mathrm{V}$ těchto lokalitách byly investovány značné prostř̌edky i do potřebné techniky pro úpravu tratí, parků aj. Lokality s modernizovanými rekreačními středisky se staly vyhledávanými, na rozdíl od řady jiných, dříve známých turistických středisek s podobnými podmínkami pro zimní sporty, avšak s jejich nedostatečnou modernizací, jako např́iklad v lokalitách Staré Hamry-Grůn̆, Bílý kříž, Pustevny, Morávka, Krásná, Visalaje, Javorový vrch, Horní Lomná, Řeka aj. (obr. 1).

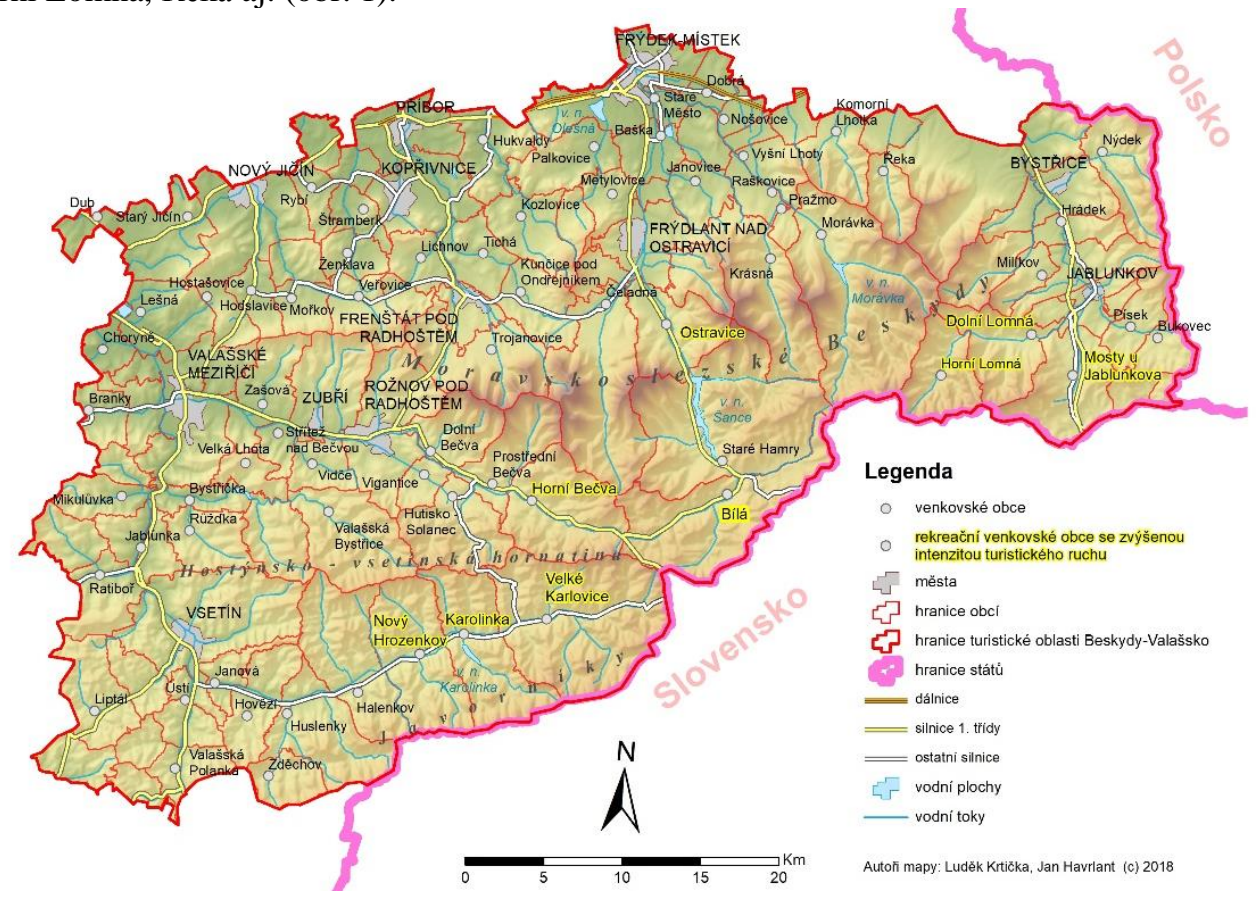

Obr. 1. Venkovské rekreační obce v turistické oblasti Beskydy-Valašsko

O zastaralá střediska, v nichž rozsáhlejší inovace nebyly realizovány, zájem návštěvníků výrazně poklesl. Nedostatečně vybavená stagnující stř̌ediska patří k sezónním, mnohem méně navštěvovaným střediskům lokálního významu. Schází v nich zejména širší doprovodná infrastruktura a služby, zvláště pro vícedenní pobyty. S inovacemi turistické infrastruktury, jakož i s nabídkou a úrovni služeb úzce souvisí velmi diferencované socioekonomické dopady i další efekty cestovního ruchu v dotčených horských obcích.

\section{Socioekonomický potenciál obce Bílá}

$\mathrm{K}$ důležitým faktorům turistické atraktivity venkovských obcí patří nejen jejich př́rodní, rekreační, ale rovněž socioekonomický potenciál. Lokální rozvoj v horské periferní oblasti ovlivnil mimo jiné nepříznivý demografický vývoj, s dlouhotrvajícím migračním úbytkem, zvláště obyvatel v produktivním věku; dále nepříznivá struktura ekonomicky aktivních osob, úroveň jejich vzdělání a kvalifikace a v neposlední řadě také nezájem místních obyvatel pracovat v dynamicky se rozvíjejících odvětvích služeb, zaměřených na cestovní ruch. V obci Bílá pře- 
trvával až do konce 90 . let minulého století problém nedostatku pracovních prríležitostí a uplatnění ekonomicky aktivního obyvatelstva v místě trvalého bydliště. $\mathrm{V}$ důsledku nepříznivého sociodemografického vývoje je dnes v obci Bílá vysoký podíl obyvatel v postproduktivním věku $(20 \%)$. Naproti tomu dětská složka tvoří v obci jen $10 \%$ z celkového počtu obyvatel (tab. 1). Nepř́iznivý trend demografického vývoje byl však v posledních dvou dekádách vystřídán mírným nárůstem počtu obyvatel Bílé (obr. 2). Klíčovou roli ve změně trendu sehrál nárůst počtu pracovních příležitostí ve službách, zaměřených na cestovní ruch a volnočasové aktivity.

Tab. 1. Věková struktura obyvatel obce Bílá (2017)

\begin{tabular}{l|cc}
\hline Věková skupina & Počet obyvatel & Počet obyvatel (\%) \\
\hline $0-14$ let & 33 & 10,6 \\
$15-64$ let & 215 & 69,4 \\
65 a více let & 62 & 20,0 \\
\hline
\end{tabular}

Zdroj: ČSÚ (2018), Místopisný průvodce po České republice (2018)

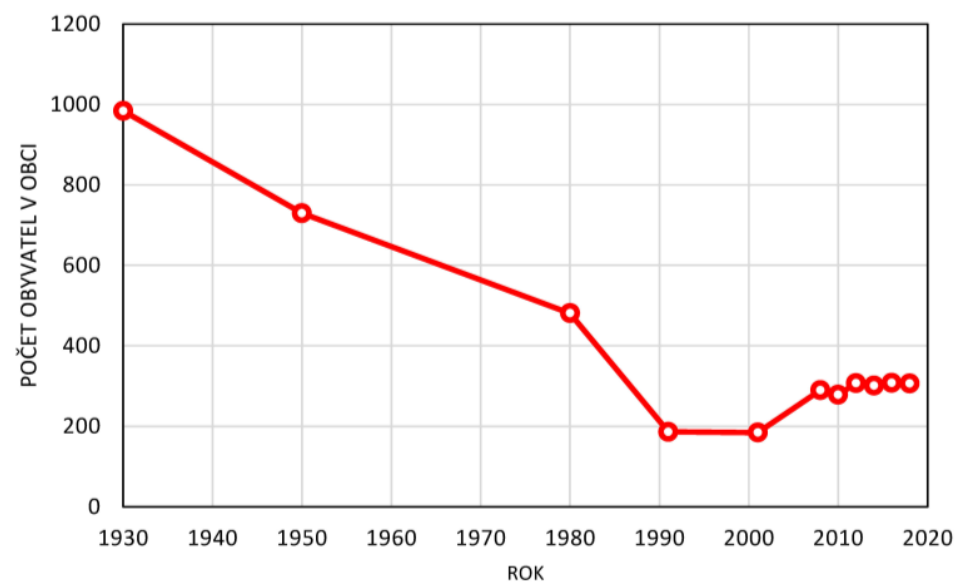

Obr. 2. Vývoj počtu obyvatel obce Bílá v období 1930-2018 Zdroj: ČSÚ (2018), vlastní zpracování

Z hlediska zaměstnanosti je $\mathrm{v}$ současnosti většina $\mathrm{z}$ cca 145 ekonomicky aktivních obyvatel Bílé zaměstnána v obci v podniku Lesy ČR anebo dojíždí za prací do měst ostravské konurbace. Jen nepatrná část ekonomicky aktivních osob je zaměstnána $\mathrm{v}$ zařízeních cestovního ruchu. Mezi potenciálními zaměstnanci je nedostatek kvalifikované pracovní síly anebo není o práci ve službách cestovního ruchu zájem. Ve třech největších hotelových zařízeních v obci je zaměstnáno jen 8 místních občanů. $Z$ hlediska vzdělanostní struktury dosahuje podíl vysokoškolsky vzdělaných osob pouze $6 \%$; středoškolské vzdělání s maturitou má jen necelá čtvrtina obyvatel starších 15 let (Šimoňáková, Diváková 2008). Mimo jiné i proto v odvětvích lesního hospodářství a zemědělství pracuje v obci až $23 \%$, zatímco v nevýrobních odvětvích jen nepatrná část ekonomicky aktivních obyvatel. Nepříznivé sociálně-ekonomické ukazatele souvisí s historickým vývojem a s důsledky periferní polohy obce. Teprve od počátku tohoto století začala v obci rozsáhlá transformace lokálních hospodářství, podnikových rekreačních zařízení a také modernizace a rozvoj nové ubytovací a sportovně-rekreační infrastruktury i různých doprovodných služeb, což se pozitivně promítlo do změn zaměstnanosti i do dalších ekonomických ukazatelů. V současnosti činí míra nezaměstnanosti v obci $6 \%$. V posledních letech dokonce vzrostla výrazně dojížd'ka za prací do obce Bílá v důsledku rozvoje rekreačních středisek a nových služeb. Převážná část zaměstnanců zdejších ubytovacích, gastronomických, sportovně-rekreačních a dalších zařízení do Bílé dojíždí z Ostravska a z obcí Podbeskydí. 


\section{Inovace sportovně-rekreační infrastruktury a růst turistické atraktivity obce}

$\mathrm{Z}$ cca 40 beskydských turistických středisek patří v posledních letech $\mathrm{k}$ nejatraktivnějším ta, která prošla rozsáhlými inovacemi a rozvojem sportovně-rekreační infrastruktury. I když rekreační střediska v Bílé nedosáhla dosud kapacitami ubytovací a doprovodné infrastruktury úrovně největších českých středisek (v Krkonoších - Špindlerův Mlýn, Harrachov, Pec pod Sněžkou) či slovenských středisek (v Nízkých Tatrách - Jasná, Donovaly, v Kysuckých Beskydech - Oščadnica-Velká Rača, aj.), přesto v rámci cestovního ruchu v Česku roste o středisko Bílá zájem ze strany domácích i zahraničních návštěvníků, a to zvláště z Polska. Bílá patři v současnosti v důsledku rozsáhlé modernizace rekreační infrastruktury k nejlépe vybaveným v celé oblasti Beskyd. Lyžařský areál v Bílé byl budován od roku 1965 dřívějším lyžařským oddílem Vítkovických železáren, který jej provozoval do začátku 90. let. V současnosti jej provozuje oddíl Ski Bílá - Služby s.r.o. Díky spolupráci veřejného a soukromého sektoru, zvláště pak díky aktivitám činovníků lyžařského klubu se podařilo v posledních letech, s využitím evropských strukturálních fondů, získat potřebné finanční prostředky na rozvojové projekty modernizace sportovně-rekreačního areálu, včetně jeho technického vybavení. Díky dobré kooperaci s řadou firem byly vybudovány nové sjezdové, běžecké i cykloturistické trasy (obr. 3), snowpark, bikepark, kidpark, wellness centrum a taktéž byla výrazně rozšířena ubytovací, stravovací i doprovodná infrastruktura v obci (obr. 4), čímž výrazně vzrostla její turistická atraktivita.

Inovace se týkaly zejména dvou ski areálů s jedním odbavovacím systémem, s 8 sjezdovými tratěmi v celkové délce $6,2 \mathrm{~km}$, včetně malého snowparku. Na severních svazích údolí byla v zimní sezóně 2007/2008 uvedena do provozu čtyř sedačková lanovka o délce $1 \mathrm{~km}$. Projekt byl financován z $80 \%$ z evropských dotačních prostředků. S dalšími 6 vleky (včetně areálu v Bílé-Mezivodí) činí přepravní kapacita celého střediska 6750 osob za hodinu. Sjezdovky jsou vybaveny výkonným zasněžovacím systémem v celé jejich délce. Samozřejmostí se stala každodenní kvalitní úprava svahů (obr. 5).

Areál byl vybaven osvětlením pro večerní lyžování. Na jižních svazích se nachází mírnější cvičné terény; strmější severní svahy nesou delší, členitější a náročnější terény i atraktivní sportovní sjezdovku s homologací FIS, využívanou také ke slalomovým závodům. Pro běžecké lyžování jsou k dispozici trasy vedoucí jak údolím Bílé Ostravice, tak hřebenovými polohami Moravskoslezských Beskyd. Při vyhovujících sněhových podmínkách se v okolí upravují běžecké stopy v délce od 5 do $70 \mathrm{~km}$. Obec Bílá se stala v oblasti zimních sportů jedničkou v celém moravskoslezském regionu. Růst turistické návštěvnosti Bílé nastal také v souvislosti s rozšiřující se nabídkou dalších volnočasových aktivit a vybavenosti střediska početnými atrakcemi, zvláště pro rodiny s dětmi. Inovace v produktové nabídce jsou přitažlivé rovněž pro segment náročnějších návštěvníků i v jiných formách cestovního ruchu (například různé eventy, vč. pracovních akcí). Rozšiřující se celoroční nabídka různých produktů a doplňkových služeb posunula Bílou v rámci Česka do kategorie kvalitních sportovně-rekreačních stř̌edisek. V současnosti jsou v obci již poměrně dobré možnosti ubytování i stravování. Modernizace rekreačních zařízení přinesla v posledních letech obci řadu pozitivních efektů. Atraktivita obce rychle vzrostla nejen výstavbou kapacitní lanovky (se zimním i letním provozem pro pěší turisty a cyklisty), ale také rožšíření systému umělého zasněžování sjezdovek přineslo prodloužení sezóny až k 130 dnům provozu. Počet návštěvníků lyžařského střediska v Bílé výrazně vzrostl od roku 2008 po modernizaci areálu. Zvláště v př́znivých sezónách s dostatkem sněhové pokrývky byl registrován až čtyřnásobný nárůst počtu návštěvníků, v porovnání s obdobím před rokem 2001 (obr. 6). 


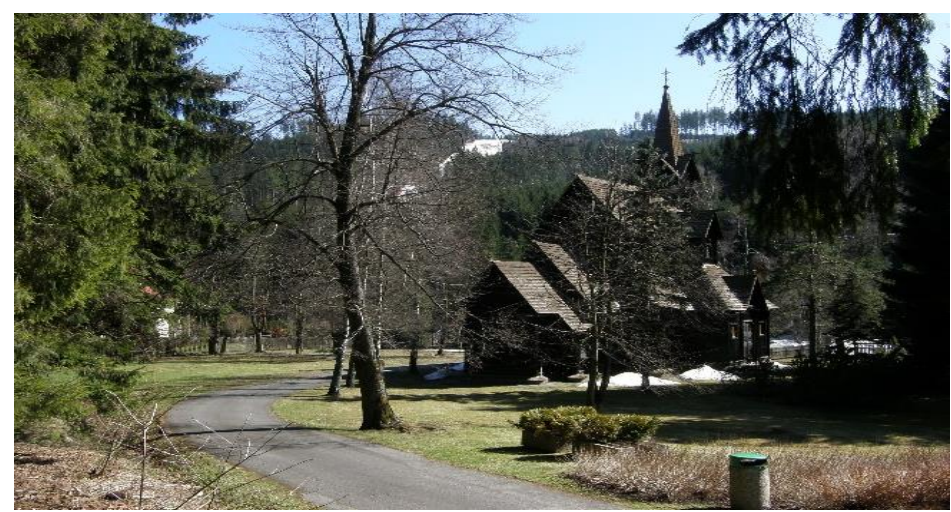

Obr. 3. Cykloturistické a lyžařské trasy v údolí Bílé Ostravice (Foto J. Havrlant 2019)

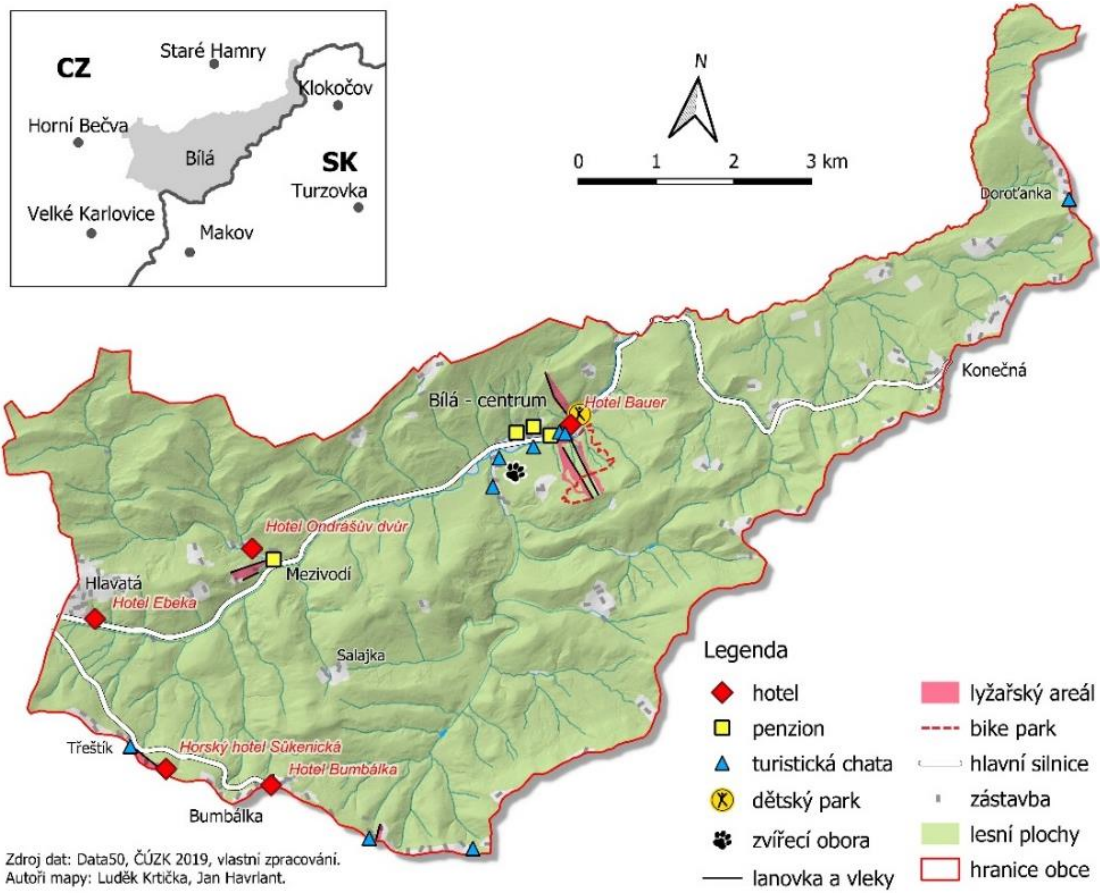

Obr. 4. Turistická a rekreační infrastruktura v obci Bílá (2019)

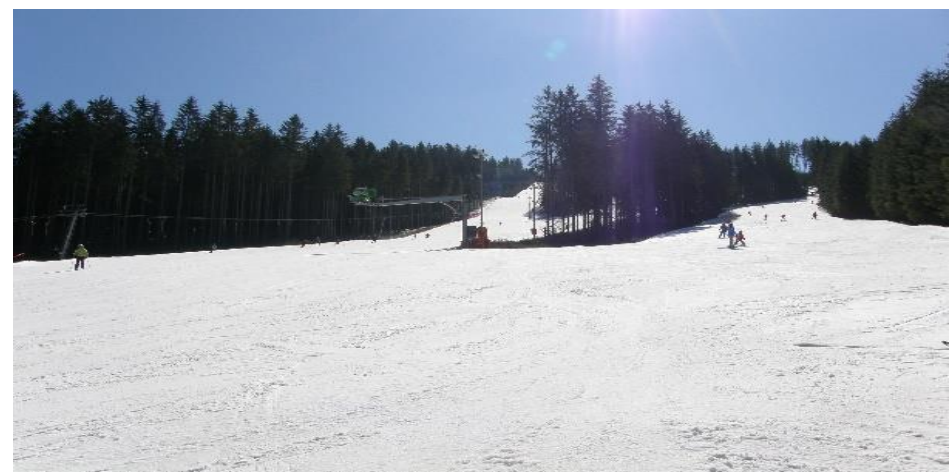

Obr. 5. Upravené svahy Ski areálu Bílá (Foto J. Havrlant 2019) 


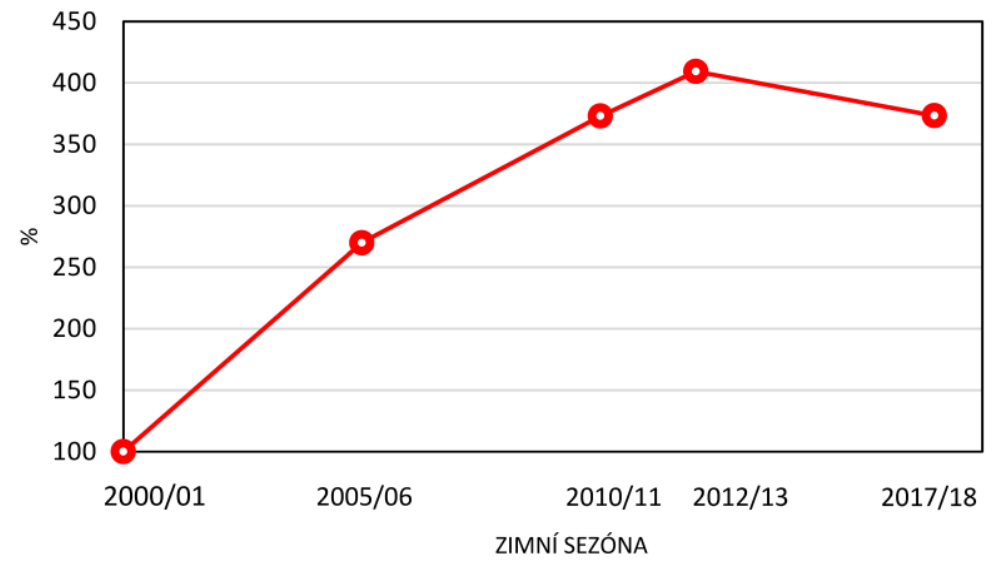

Obr. 6. Index návštěvnosti lyžařského areálu Bílá, 2000-2018 (sezóna 2000/01 = 100\%) Zdroj údajư: Ski areál Bílá (2018), výpočty autora

V posledních letech dosahuje průměrný počet návštěvníků ski areálu kolem 110 tisíc. Taktéž průměrná denní návštěvnost výrazně vzrostla po inovacích střediska (tab. 2). Během jednoho dne návštěvníci ski areálu absolvovali v průměru 12,5 jízd, většinou s využitím čtyřsedačkové lanovky.

V obci Bílá se v posledních 10 letech současně rozšśřila nabídka nových produktů, zvláště pro mládež a rodiny s dětmi. Součástí střediska je dětský skipark, lyžařská a snowboardová škola. Lyžařská škola s půjčovnou vybavení je součástí největší sítě lyžařských škol v Česku, která působí ve 20 zimních střediscích. Skipark se školou patří od roku 2008 k nejmodernějším dětským skiparkům v Česku. S pojízdným kobercem, krátkým lanovým vlekem zajištuje veškerý komfort při výuce lyžování a snowboardingu. V půjčovně je k dispozici přes 300 kompletů lyžařského a snowboardového vybavení. Nové modely lyží jsou však k dispozici jen v omezeném počtu a zdaleka neuspokojují zájem návštěvníků, což představuje další př́ležitost pro inovace.

Tab. 2. Vývoj návštěvnosti a provozních dnů Ski areálu Bílá v letech 1998-2018

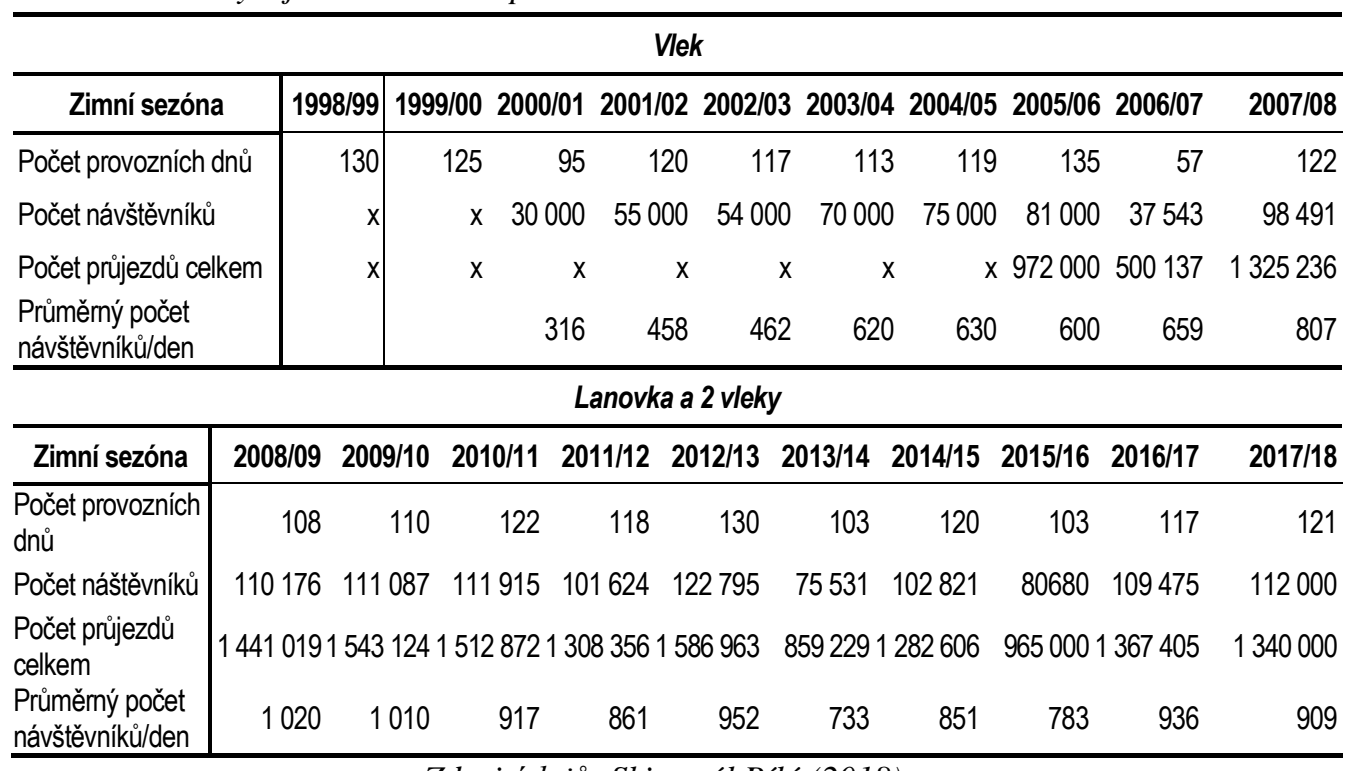


V obci Bílá došlo k rozšíření i dalších možností volnočasových aktivit. Návštěvníkům je $\mathrm{k}$ dispozici široká sportovně-rekreační a doplňková infrastruktura, mj. ledová plocha na víceúčelovém hřišti, umělá lezecká stěna, krytý bazén s wellness centrem u hotelu Bauer aj. Pro letní a mimo sezónní aktivity zde slouží tenisové kurty, hřiště pro míčové hry, dětská hřiště, dětská auta a další atrakce, využívané zejména rodinami s dětmi. Možnosti dalšího vyžití v obci rozšiŕíilo vybudování adrenalinového bike parku se čtyřmi single traily o celkové délce 10 km, které jsou lokalizovány na náročné severní sjezdovce. Cyklisté mohou využít lanovky k vývozu kol. V zázemí areálu byl otevřen pro děti tzv. Zbojnický chodník. K dalším novým atrakcím v obci náleží trampolínové centrum, dětský lanový areál, tubing aj.

$\mathrm{Z}$ iniciativy obce, která v posledních letech akcentuje rozvoj cestovního ruchu řadou vlastních aktivit a investic, byla údolím Bílé Ostravice vybudována cyklostezka mimo silniční komunikaci. V dalších letech má být vybudován nový úsek cyklostezky, směřující z Bílé na Valašsko do Velkých Karlovic a Horní Bečvy. Obec byla rovněž iniciátorem vybudování tzv. „Pašerácké stezky“ (atrakce pro děti) a malé obory (1,7 ha). Obec se podílí také na údržbě lyžařských běžeckých stop. V nedávné době obec podpořila projekt rozšíření Ski areálu Bílá-jih. $\mathrm{K}$ růstu její turistické atraktivity významně přispívá také řada různých akcí, pořádaných $\mathrm{v}$ průběhu roku. V letní sezóně roste zájem o týdenní nebo víkendové cyklo a inline campy, o výjezdové tábory a speciálně zaměřené pobytové tábory pro děti. V zimní sezóně jsou vyhledávány bezplatné prezentace s testováním lyží špičkových zahraničních výrobců, dále závody ve slalomu pro veřejnost (akce organizovaná s Českou televizí) anebo různé promo akce např́klad výrobců osobních automobilů. Do nově nabízených produktů pro rodiny s dětmi jsou zapojeni taktéž aktéři v sousedních horských obcích. S dětským parkem v Bílé úzce spolupracuje tzv. Vodní svět a Razulák ve Velkých Karlovicích se zcela novými atrakcemi aj. Zvýšený zájem o krátkodobé i dlouhodobé pobyty v Bílé souvisí též s cenovým zvýhodněním a s různými bonusy, které nyní nabízí většina hotelů. Podobně jako v alpských střediscích, ubytovaní hosté mají k dispozici tzv. kartu hosta, umožňující levnější pobyty a slevy na vleky, bazén, do wellness centra i na další atrakce. Zvláště výhodné jsou vícedenní pobyty pro rodiny s dětmi, na něž se rekreační stř̌ediska zaměřují stále více. Dříve jen sezónní využití rekreačních středisek se změnilo na celoroční, čímž významně vzrostla jejich atraktivita, návštěvnost i přínosy pro obec. Rostoucí turistickou atraktivitu obce dokládá index turistické funkce (ITF). V obci Bílá dosahuje v současnosti ITF hodnoty 3,5; což je 2,5 krát vyšší hodnota než na konci 70. let minulého století (včetně započtení tehdy převažujících ubytovacích kapacit v podnikových zařízeních) (Havrlant 1977). Po odečtení těchto vázaných kapacit dosahoval v před transformačním období ITF hodnoty pouhých 0,36 . Při porovnání ITF za čtyři dekády je v obci Bílá patrný až desetinásobný nárůst indikátoru, dokladujícího výrazný růst turistické atraktivity horské obce.

\section{Inovace infrastruktury hromadných ubytovacích zařízení}

Inovace turistické infrastruktury zahrnovaly modernizaci ubytovacích, stravovacích a dalších doplňkových zařízení. Přinesly celkové zvýšení úrovně a konkurenceschopnosti rekreačních středisek. Modernizací prošla většina hromadných ubytovacích zařízení v obci Bílá. Dř́ivější odborářská zotavovna Pokrok, od 90. let pak hotel, se po rozsáhlé rekonstrukci stal v roce 2015 špičkovým ubytovacím zařízením v obci. Současný Wellness hotel Bauer (obr. 7), s ubytovací kapacitou cca 122 lůžek, doznal výrazných kvalitativních změn.

Wellness hotel dnes nabízí ubytování v komfortních pokojích. Součástí hotelového komplexu jsou dvě dependance s kapacitou cca 100 lůžek. Wellness centrum nabízí relaxaci v bazénu s protiproudem, whirpool, saunu, masáže, fitness tělocvičnu aj. $\mathrm{O}$ wellness centrum roste zájem nejen mezi ubytovanými. Hotelová restaurace se stylovou horskou jizbou (s 200 místy) nabízí českou i tradiční valašskou gastronomii. Konferenční sál je koncipován pro pracovní, kulturně-společenské a podobné akce. Hotel Bauer zaměstnává v zimní a letní sezóně cca 36 pracovníků (recepční, číšníci, kuchaři, pracovníci wellness centra, různé pomocné síly), v mimo sezóně pak o třetinu méně. Možnosti rychlého občerstvení zajišt’ují u hotelu Bauer Gril srub 
a další tři stánkové objekty. Využití ubytovacích kapacit hotelu bývá v průběhu roku diferencované. V hlavní zimní sezóně (od vánočních svátků do konce března), dosahuje využití lůžkových kapacit až 90 \%. V jarní a podzimní mimo sezóně, trvající necelé 4 měsíce, klesá využití lůžkových kapacit na přibližně 40 \%. Průměrné celoroční využití kapacit hotelu dosahuje $55 \%$. Př́znivé ekonomické ukazatele a přínosy souvisí s řadou inovací a s rozšiřující se nabídkou doprovodných služeb hotelu, jakož i s rozšiřující se spolupráci s dalšími aktéry ve středisku i v sousedních obcích. V lokalitě Bílá-Mezivodí rozširíil nabídku nových produktů menší Wellness hotel Ondrášův Dvůr (s kapacitou cca 40 lůžek, včetně 3 chat a apartmánu). Od roku 2015 hotel nabízí kvalitní ubytování a gastronomii s valašskými specialitami i řadu doprovodných služeb a produktových balíčků, zahrnujících mj. využití originálního Thermal parku a wellness centra. Doplňková infrastruktura zahrnuje venkovní bazén, víceúčelovou krytou halu, tenisový kurt, hřiště, dětský areál a další atrakce. Díky široké nabídce roste zájem o pobyty ze strany zahraničních turistů, zejména ze Slovenska, Polska i z Velké Británie. Cizinci tvoří až $30 \%$ hotelových hostů. Hotel zaměstnává celoročně cca 35 pracovníků. Většina zaměstnanců hotelu dojíždí do Bílé z Ostravska a z Valašska. Využití lůžkových kapacit je v průběhu roku diferencované. V letní a zimní sezóně dosahuje přes $80 \%$, v mimosezóně kolem $35 \%$. Průměrné celoroční využití kapacit hotelu dosahuje v posledních letech kolem 60 \%. V Bílé Mezivodí je nově v provozu také kvalitní pension Ledovec (cca 20 lůžek), který rozš́íril nabídku ubytování v menším lyžařském areálu. V ubytovacích zařízeních stř̌ední třídy, jakými jsou hotely Sůkenická (s 58 lůžky) a Ebeka (s 84 lůžky) je využití jejich kapacit obdobné (v průměru přes $60 \%$ ). Rozdíl je ale $\mathrm{v}$ zanedbatelném podílu zahraničních hostů. V roce 2016 byly v Bílé otevřeny nové apartmány Na Faře (s cca 34 lůžky). Ke starším ubytovacím zařízením s větší kapacitou patří v obci Turistická chata Bílá (s 84 lůžky), dřive podnikové rekreační zařízení Vítkovických železáren. Chata si zachovala ubytování ve vícelůžkových pokojích a je vybavena jen kuchyní $\mathrm{s}$ jídelnou. Obsazována je především v zimní a letní sezóně školními kurzy a v jarním období školami $\mathrm{v}$ prírodě. $\mathrm{V}$ sezóně dosahuje obsazenost zařízení kolem $75 \%$, v mimosezóně klesá pod $50 \%$. Pension Hájenka (s 20 lůžky) byl nedávno rekonstruován a vybaven malou restaurací s barem. Chata lyžařského klubu Bílá (s 33 lůžky) je využívaná zejména členy oddílu. Originální dřevěný Lovecký zámeček (postaven v roce 1906) je v současnosti ve vlastnictví Ostravsko-opavské diecéze a slouží jako zařízení vázaného i volného cestovního ruchu. Možnosti levného ubytování, avšak nízké kvality, nabízí dřivější internát SOŠ lesnické. Vícelůžkové pokoje v ubytovně (s cca 180 lůžky) jsou využívány především školními kurzy. Celková ubytovací kapacita pro volný cestovní ruch dosahuje v obci Bílá v současnosti téměř 1100 lůžek (tab. 3).

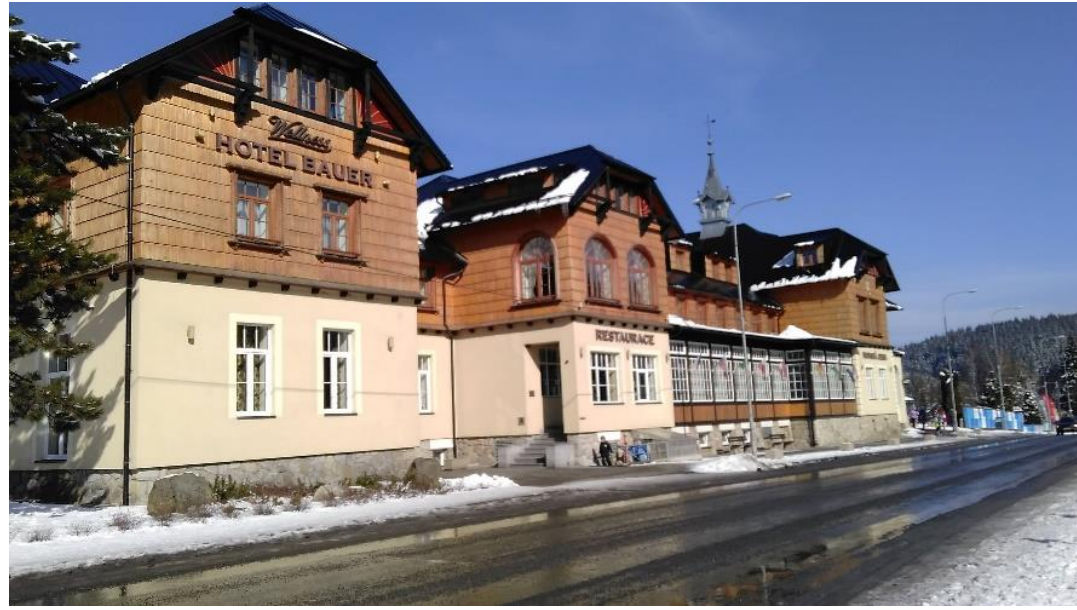

Obr. 7. Modernizovaný Wellness hotel Bauer, dřivější zařizení vázané rekreace (Foto J. Havrlant 2019) 
Ve vztahu k počtu trvale bydlících obyvatel je zřejmé, že obec Bílá je dnes typickou rekreační obcí, v níž ubytovací kapacita, využitelná v cestovním ruchu 3,5 násobně převyšuje počet místních obyvatel (bez kapacit objektů druhého bydlení, které nelze využít ve volném cestovním ruchu). V posledních 10 letech se v obci vedle navýšení ubytovací kapacity současně zvýšila kvalita ubytování i dalších doplňkových služeb u většiny hromadných ubytovacích zařízení. Na rozdíl od velkých krkonošských nebo tatranských turistických středisek, v obci Bílá jen ojediněle podnikají v ubytovacích službách rezidenti. V obci je registrováno pouze 5 místních ubytovatelů, nabízejících ubytovací služby v soukromí rodinného domu. Ubytovací kapacita těchto privátních pokojů v Bílé dosahuje oficiálně jen 44 lůžek.

Tab. 3. Ubytovací zařizení a jejich vybavenost v obci Bílá (stav k 31. 12. 2018)

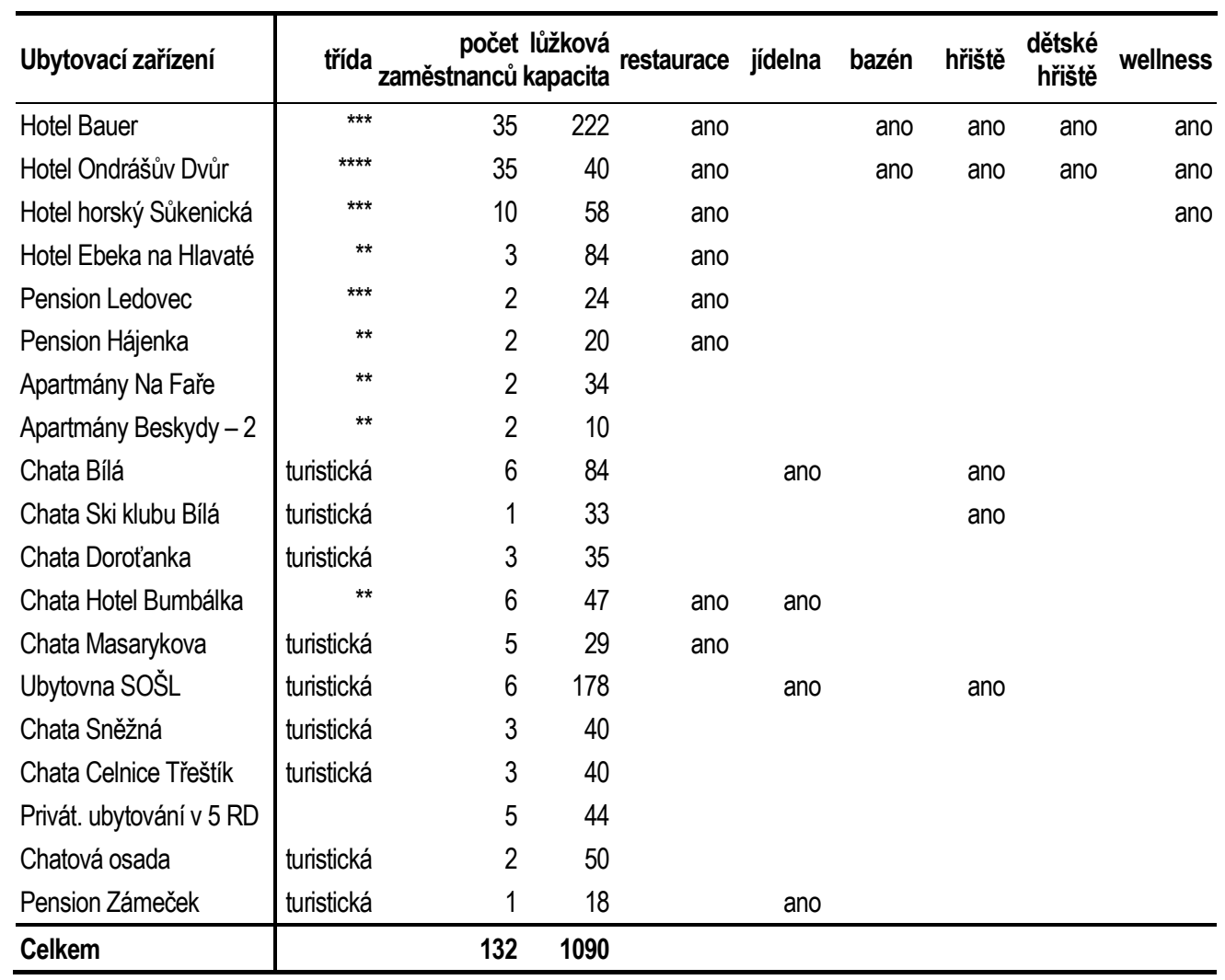

Zdroj: dotazníkové šetření (2018), Obec Bílá, oficiální stránky obce, ubytování (2018)

\section{Socioekonomické přínosy cestovního ruchu v obci}

Cestovní ruch v obci Bílá generoval v posledních letech řadu multiplikačních efektů, včetně socioekonomických přínosů. Významně se podílí především na vytvoření nových pracovních př́ležitostí v sektoru služeb. V důsledku dynamického rozvoje turistické, sportovně-rekreační, zábavní a dopravní infrastruktury, jakož i základních a doprovodných služeb se zvýšil počet trvalých i sezónních pracovních míst v obci. V současnosti pracuje ve službách cestovního ruchu v obci (se 145 ekonomicky aktivními rezidenty) téměř 300 zaměstnanců, z nichž přibližně $60 \%$ tvoří stálí zaměstnanci v ubytovacích, gastronomických a rekreačních zařízeních (tab. 4).

Ski areál Bílá zaměstnává celoročně 15 , v zimě pak 35 pracovníků. V zimní sezóně pracuje ve ski areálu 22 lanovkářů, vlekařŭ, řidičủ a zaměstnanců půjčovny a servisu. Polovina z nich v mimo sezóně vykonává potřebné údržbářské činnosti (opravy, kosení trávy, úpravy a značení cyklostezek a další práce). Ski servis rozšíríil své činnosti také do letní sezóny, kdy funguje 
jako cyklo servis. Trvalé uplatnění v něm mají zatím 2 zaměstnanci. Další pracovní př́iležitosti ve ski areálu vznikly v pohostinských a úklidových službách. Restauraci a venkovní stánky s občerstvením obsluhuje v hlavní sezóně 9 zaměstnanců. Samostatnou společností, bezprostředně kooperující se Ski areálem Bílá, je společnost Sun Ski, zaměstnávající 11 stálých pracovníků a přes 60 sezónních zaměstnanců, především instruktorů lyžování a snowboardingu. V Bílé je lokalizována také základna Horské služby, zajištující zdravotnické služby první pomoci. Na základně slouží dva stálí záchranáři s plným pracovním úvazkem, avšak v hlavní zimní sezóně zajišt'uje službu dalších 10 dobrovolných pracovníků Horské služby. Efekty turismu však přesahují rámec obce. V posledních letech se rozvinuly specifické sezónní služby dopravců. Do oblasti Beskyd byly zavedeny jak pravidelné sezónní ski busy a cyklobusy z Ostravy, tak nepravidelná autokarová doprava z měst Moravskoslezského a Zlínského kraje, ale také z Polska. Zájezdovou dopravu organizují většinou školy pro své lyžařské kurzy. Podle odhadu managementu Ski areálu Bílá tvoří účastníci školních kurzů a jednodenních lyžařských zájezdů asi desetinu všech návštěvníků střediska. V zimní sezóně přijiźždí do Bílé v průměru kolem 6 autokarů denně (Interní dokumenty Ski areálu Bílá, 2018). Novinkou zavedenou v roce 2019 je zřízení nepravidelné autobusové dopravy „na zavolání“ v trase BíláBumbálka - Mezivodí - Bílá-Konečná, která je vhodná zejména pro pěší turisty a běžkaře.

Tab. 4. Počet zaměstnanců ve službách cestovního ruchu v obci Bílá v roce 2018

\begin{tabular}{l|rrrr}
\hline Zařizení & $\begin{array}{r}\text { stálí } \\
\text { zaměstnanci }\end{array}$ & $\begin{array}{r}\text { sezónní } \\
\text { zaměstnanci }\end{array}$ & $\begin{array}{r}\text { zaměstnanci } \\
\text { celkem }\end{array}$ & poznámka \\
\hline Ski areál Bílá & 15 & 20 & 35 & \\
Společnost Sun Ski & 11 & 61 & 72 & \\
Hotel Bauer & 25 & 10 & 35 & 5 rezidentů \\
Hotel Ondrášưv Dvưr & 35 & 0 & 35 & 1 rezident \\
Hotel Sůkenická & 9 & 1 & 10 & 1 rezident \\
Hotel Ebeka & 3 & 0 & 3 & 1 rezident \\
UZ Chata Bílá & 5 & 1 & 6 & \\
Ubytovna - zařízení SoŠL & 3 & 3 & 6 & \\
Horská služba & 2 & 10 & 12 & \\
restaurace areálu, gril a bufety & 0 & 12 & 12 & \\
skiservis, cykloservis, půjčcovny & 4 & 3 & 7 & \\
pensiony, apartmány, tur. chaty & 35 & 0 & 35 & \\
ubytovatelé v rodin. domech & 6 & 0 & 6 & 6 rezidentů \\
řdiči ski busů a zájezdových autokarů & 0 & 6 & 6 & \\
obchod potravin a občerstvení & 3 & 0 & 3 & 2 rezidenti \\
prodejci lokálních specialit & 0 & 2 & 2 & \\
\hline Celkem & 156 & 129 & $\mathbf{2 8 5}$ & \\
\hline
\end{tabular}

Zdroj: terénní výzkum, dotazníkové šetření (2018)

Obec Bílá, díky podpoře cestovního ruchu, má v posledních letech zajištěn ziskový rozpočet. Důležitým rozvojovým impulsem zde byla v 90 . letech transformace bývalých zařízení podnikové rekreace, které byly v Beskydech v 60. až 80. letech dominantní. Kapacity těchto zařízení tvořily v Bílé 73 \% z celkové lůžkové kapacity 714 lůžek (Havrlant 1977). V 90. letech se dvanáct z třinácti zařízení vázaného cestovního ruchu transformovalo na komerční hromadná ubytovací zařízení, využitelná ve volném cestovním ruchu (obr. 8). 


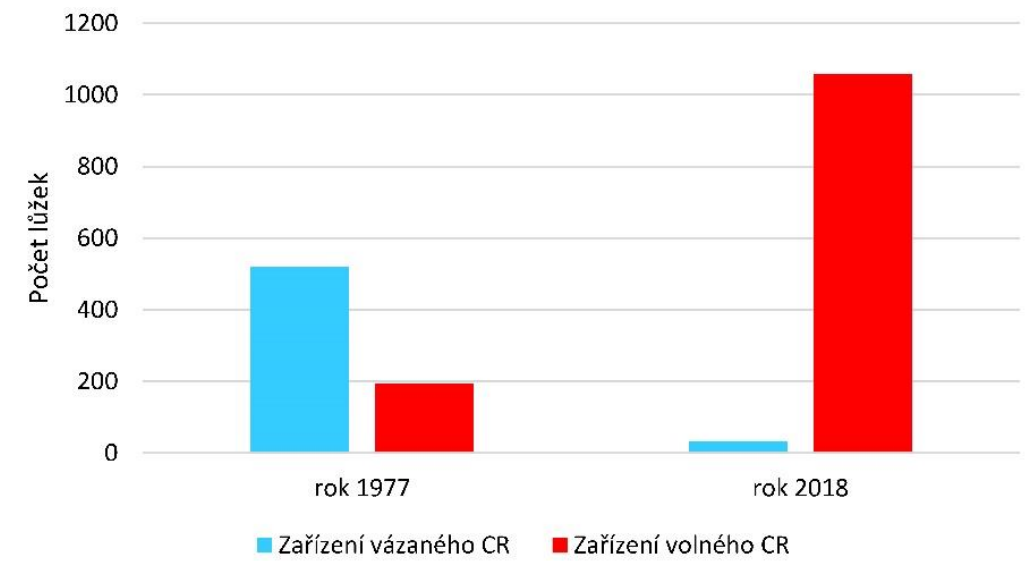

Obr. 8. Lůžkové kapacity v obci Bílá v hromadných ubytovacích zařizeních volného a vázaného cestovního ruchu v letech 1977 - 2018 Zdroj údajů: Havrlant, M. (1977), dotazníkové šetrení (2018)

Dřive jen ojedinělá ubytovací zařízení volného cestovního ruchu (hotely Súkenická, Ebeka a tři turistické chaty) disponovaly ubytovací kapacitou cca 194 lůžek, avšak neposkytovaly prakticky žádné doplňkové služby (Havrlant 2000). Modernizace ubytovací infrastruktury a rozvoj nových typů zařízení (pensionů a apartmánů) přinesly obci od roku 1996 více než osmdesáti násobný nárůst př́ijmů do obecního rozpočtu v položkách poplatků za rekreační pobyty ubytovaných hostů a poplatků z ubytovacích kapacit*. Významné jsou také pŕíjmy z pronájmů nemovitostí, zařízení a pozemků v majetku obce, na nichž je lokalizována část ski areálu. Př́jimy z ubytovacích zařízení a $\mathrm{z}$ pobytů turistů vzrostly v rámci celkových př́ijmů obce v posledních dvou letech až na $6 \%$ (tab. 5). Avšak s pronájmem pozemků a sportovněrekreačních zařízení dosáhly tyto příjmy dokonce $23 \%$ na celkových př́ijmech obce (Ministerstvo financí ČR 2018).

Tab. 5. Vývoj príjmů vybraných položek z cestovního ruchu do rozpočtu obce v letech $1996-2018$ (v tis. Ǩ́)

\begin{tabular}{|c|c|c|c|c|c|c|c|c|c|c|c|c|}
\hline Položka /rok & 1996 & 2001 & 2006 & 2010 & 2011 & 2012 & 2013 & 2014 & 2015 & 2016 & 2017 & 2018 \\
\hline alatk & 5,9 & 178,5 & 167,7 & 180,3 & 183,3 & 136,8 & 98,6 & 194,0 & 364,1 & 114,2 & 505,0 & 474,7 \\
\hline platky & 3,8 & 125,5 & 123,7 & 140,2 & 140,2 & 124,5 & 120,8 & 147,0 & 292,5 & 124,3 & 338,5 & 302 \\
\hline $\begin{array}{l}\text { oplatky z pobytů a ubytovací } \\
\text { apacity celkem }\end{array}$ & 9,7 & 304,0 & 291,4 & 320,5 & 323,5 & 261,3 & 219,4 & 341,0 & 656,6 & 238,5 & 843,5 & 777 \\
\hline $\begin{array}{l}\text { Dronájem pozemků a zařizení } \\
\text { / majetku obce ke sport.- } \\
\text { ekreačním účelům }\end{array}$ & $x$ & $x$ & $\mathrm{x}$ & 2863 & 2614 & 2201 & 2306 & 1136 & 2240 & 1737 & 2457 & 2480 \\
\hline Oozpočtové přjimy celkem & $\mathrm{x}$ & $x$ & & 20125 & 17570 & 11850 & 21917 & 11515 & 16330 & 13667 & 13997 & 1453 \\
\hline $\begin{array}{l}\text { Podíl přijmů z rekreač. pobytů } \\
\text { a ubytovacích kapacit na } \\
\text { celkových přijmech obce (\%) }\end{array}$ & $x$ & $\mathrm{x}$ & $\mathrm{x}$ & 1,6 & 1,8 & 2,2 & 1,0 & 3,0 & 4,0 & 1,8 & 6,0 & 5 \\
\hline
\end{tabular}

Zdroj údajů: Ministerstvo financí $\check{C} R$ (2018), pozn. $x$ - údaje nejsou $k$ dispozici

*Zastupitelé obce zmiňuji problém s výběry poplatků z ubytování u některých „,malých “ ubytovatelù. Podle nepotvrzených odhadi̊ nepriznává poskytování ubytovacích služeb asi čtvrtina ubytovateli̊ - vlastníků pokojů v rodinných domech a vobjektech druhého bydlení. 


\section{Diskuze}

Cílem studie bylo zhodnotit změny turistické atraktivity venkovských obcí v horské oblasti Beskyd po společenských změnách a pádu totalitního systému. V 90. letech došlo v zájmovém území k rozsáhlé transformaci dřívějších podnikových rekreačních středisek, které zde svými ubytovacími kapacitami výrazně převládaly nad komerčními ubytovacími zařízeními. Současně zde došlo k rozvoji nové turistické infrastruktury a k rozvoji doprovodných služeb, jakož i k dynamickému rozvoji rekreační funkce některých obcí. Záměrem případové studie bylo také zhodnotit rozvoj cestovního ruchu v periferním př́hraničním území a na příkladu obce Bílá zhodnotit jeho socioekonomické a demografické dopady. V zájmové obci byla $\mathrm{v}$ posledních letech realizována řada projektů, zaměřených na rozvoj turismu, což přineslo obci řadu pozitivních efektů i změny ve využití potenciálu území.

Z hlediska typů venkovských prostorů, definovaných Perlínem, Kučerou, Kučerovou (2010), nesla příhraniční oblast Beskyd dlouho prakticky všechny znaky vnějších moravských periférií, a to úbytek počtu obyvatel, nízkou hustotu osídlení, stárnutí obyvatelstva v důsledku dlouhodobého nepříznivého demografického vývoje, nižší vzdělanostní úroveň obyvatelstva, vysoký podíl objektů druhého bydlení a vázané rekreace, nedostatečnou technickou infrastrukturu, větší vzdálenost k hlavním dopravním tahům celostátního významu, málo pracovních př́ležitostí a malý počet podnikatelských subjektů, vyšší zaměstnanost v primárním sektoru a vysokou vyjížd'ku ekonomicky aktivních obyvatel za prací především do městských center ostravské konurbace i vyšší míru nezaměstnanosti. Od počátku 21. století se však postavení některých horských obcí začalo postupně měnit. Lokální rozvoj, zaměřený na cestovní ruch, $\mathrm{s}$ akcentem na celoroční využití potenciálu území, posunul obec do jiné kategorie venkovských obcí. Výzkum potvrdil, že v Bílé a v několika sousedních obcích se nepříznivý trend, typický pro periférie, změnil. Obce s širším rekreačním potenciálem a s novou turistickou infrastrukturou byly stabilizovány a některé z nich se zařadily do kategorie intenzívně využívaných rekreačních oblastí (Perlín, Kučera, Kučerová 2010). V zájmovém území Beskyd zaznamenaly vedle Bílé obdobný vývoj také obce Ostravice, Mosty u Jablunkova, Lomná, Velké Karlovice, Nový Hrozenkov a Horní Bečva. V těchto horských obcích došlo k posílení jejich rekreační funkce, zejména ve formách volného cestovního ruchu. Současně došlo k růstu jejich návštěvnosti, turistické atraktivity i konkurenceschopnosti na trhu cestovního ruchu. Podobný trend rozvoje cestovního ruchu je sledován rovněž v některých dalších horských oblastech Česka, například v Krkonoších a na Šumavě (Horáková, Fialová 2014) anebo v polských Beskydech (Pietrzyk Sokulska 2006). Cestovní ruch se v horských obcích stal důležitým hospodářským odvětvím. V beskydských obcích se v posledních letech výrazně snížila míra nezaměstnanosti a současně stoupla zaměstnanost ve službách cestovního ruchu. Podíl vyjížd'ky i dojížd’ky za prací (v důsledku nevyhovující kvalifikační struktury rezidentů pro nová odvětví služeb) zůstává ale poměrně vysoký. Avšak záporné migrační saldo v těchto venkovských obcích v posledních letech klesá. Naproti tomu přibývá podíl nových domů, včetně objektů typu pensionů. Rizika dominance cestovního ruchu, jako jediného hospodářského odvětví, která zmiňují ve studii Horáková a Fialová (2014), však v zájmovém území Beskyd (s tradičně silnými socioekonomickými vazbami na průmyslovou oblast Ostravska) nehrozí. Značná část ekonomicky aktivních osob v těchto venkovských obcích je pořád zaměstnána ve výrobních odvětvích.

Změnami turistické atraktivity horských obcí v sousedním polském regionu Slezských Beskyd se zabývala Pietrzyk Sokulska (2006). V několika obcích, s široce rozvinutou a kvalitní základní a doprovodnou turistickou infrastrukturou, se růst jejich atraktivity promítl do pozitivních demografických a socioekonomických změn i do situace na trhu práce, jakož i do přilákání nových investorů do rekreačních a lázeňských obcí, což se pozitivně promítlo také do rozvoje nové komunální infrastruktury (dobrým prríkladem jsou např́klad obce Wisla, Szczyrk, Ustroň, Istebna a další). Podobný vývoj potvrdila i př́ípadová studie v zájmovém území obce Bílá, kde v důsledku rozvoje a modernizace turistické infrastruktury a rủstu návštěvnosti v obci přibyly nové podnikatelské aktivity i pracovní př́ležitosti. Nárůst trvalých 
i sezónních pracovních příležitostí souvisí s vybudováním nových ubytovacích a gastronomických zařízení i s rozvojem specifických doplňkových služeb, např́íklad lyžařské a snowboardové školy, servisu a půjčoven, ale také např. služeb prodejců lokálních produktů atd. Turistickou atraktivitu obcí, vyjádřenou ukazatelem intenzity turistického ruchu, zkoumali u nás od konce 60. let Šprincová (1969), Havrlant (1977), Mariot (1983), později pak sledovali modifikovaný indikátor turistické funkce obcí Pásková, Zelenka (2002); Fialová (2014) a další. V př́ípadové studii byly využity metody Páskové, Zelenky (2002) a Havrlanta (1977) především proto, že bylo možné zhodnotit v zájmovém území vývoj uvedených ukazatelů na základě změn kapacit hromadných ubytovacích zařízení a vývoje počtu rezidentů za více než 40 let. Studie potvrdila rostoucí turistickou atraktivitu horských obcí s podobným potenciálem a srovnatelnými investicemi do inovací rekreační infrastruktury. V obci Bílá dosahuje v současnosti ITF hodnoty 3,5; což je 2,5 krát vyšší hodnota než v 70. a 80. letech minulého století, kdy tento ukazatel dosahoval hodnoty 1,4 (při započtení tehdy výrazně převažujících ubytovacích kapacit $\mathrm{v}$ podnikových rekreačních zařízeních). Po odečtení těchto vázaných kapacit (tehdy nevyužitelných ve volném cestovním ruchu) dosahoval ITF v před transformačním období hodnoty pouhých 0,36 . Na základě komparace indikátoru ITF za čtyři dekády je tak v obci Bílá patrný až desetinásobný nárůst ukazatele, dokladujícího výrazný vzestup turistické atraktivity obce. Podobný trend vykazuje v posledních letech jen několik beskydských obcí. Př́ikladem jsou Velké Karlovice (ITF 1,6) Horní Lomná (ITF 1,2); nižší hodnotu indikátoru mají pak obce Dolní Lomná, Mosty u Jablunkova, Ostravice a Nový Hrozenkov. V rámci celého turistického regionu Severní Morava a Slezsko mají vyšší ITF jen specifické horské obce v oblasti Jeseníků-Malá Morávka, Karlov (ITF 3,6) a Ostružná (ITF 6,8), v nichž došlo ve druhé polovině 20. století $\mathrm{v}$ důsledku jejich vysídlení $\mathrm{k}$ rozsáhlé proměně původního domovního fondu na rekreační objekty. Dủležitým impulsem v lokálním rozvoji byly změny funkce dřívějších zařízení vázaného cestovního ruchu. V průběhu 90 . let se tato zařízení většinou transformovala na ubytovací zařízení typu pensionů, hotelů a apartmánů. Po roce 2000 pak nastoupila modernizace většiny ubytovacích zařízení a současně došlo $\mathrm{k}$ výstavbě několika nových menších pensionů a k rozvoji volného cestovního ruchu. Tyto změny se následně promítly do širších socioekonomických efektů turismu a do růstu př́ijmů z cestovního ruchu do rozpočtů obcí. Z hlediska těchto dopadů cestovního ruchu na lokální a regionální úrovni, které jsou v odborné literatuře zmiňovány (Hall, Page 1999, Vellas 2011, Vystoupil, Šauer 2006 aj.) lze na základě analýzy vybraných statistických dat a šetření v obcích konstatovat, že tyto dopady jsou v oblasti Beskyd značně diferencovány. V obci Bílá byly podrobeny analýze rozpočty obce, zvláště pak jejich př́ijmové položky v ukazatelích př́ijmů z cestovního ruchu. Rovněž byly sledovány aktivity a výdaje obce na rozvoj cestovního ruchu. K tomu směřovala dotazníková šetření a rozhovory se zastupiteli samosprávy a dalšími aktéry v zájmovém území. Analýza prokázala, že cestovní ruch v posledních dvou dekádách navýšil př́ijmy do rozpočtu obce v položkách poplatků z rekreačních pobytů a $\mathrm{z}$ ubytovacích kapacit osmdesáti násobně. Další př́ijmy plynuly z pronájmů pozemků a zařízení v majetku obce pro účely rekreačního využití. V současnosti se uvedené prríjmy podílejí až $23 \%$ na celkových př́ijmech obce. Součástí analýz byl rovněž vývoj pracovních přiležitostí a zaměstnanosti ve službách cestovního ruchu, které situaci na trhu práce výrazně ovlivňují, což zmiňují ve studiích Pietrzyk Sokulska (2006) nebo Vellas (2011). Šetření v obci Bílá prokázala nárůst trvalých i sezónních pracovních míst, zvláště pak v poslední dekádě, po vybudování nové sportovně-rekreační infrastruktury. Z hlediska multiplikačních efektů cestovního ruchu, uváděných v odborné literatuře (Vystoupil, Šauer 2006, Vellas 2011, Horáková, Fialová 2014) lze v zájmovém území sledovat i efekty $\mathrm{s}$ širšími dopady, přesahujícími rámec sledované obce. $\mathrm{V}$ posledních letech se zde rozvinuly např́klad specifické sezónní služby dopravců. Do rekreačních lokalit Bílé byly zavedeny jak pravidelné sezónní autobusové spoje - skibusy a cyklobusy z měst ostravské konurbace, tak nepravidelná autokarová doprava z jiných regionů (školní sportovní kurzy, zájezdy apod.). 
Výzkum v zájmovém území také potvrdil, že v rozvoji turismu má dnes klíčový význam mnohostranná spolupráce všech zainteresovaných lokálních aktérů, na níž upozorňují ve studiích např́klad Farrell a Thirion (2000), Kulla (2011) aj. Díky kooperaci místních samospráv, veřejného a soukromého podnikatelského sektoru se daří výrazně měnit atraktivitu obcí, což potvrdil výzkum i v jiných turistických regionech, např́klad v Polsku (Mika, Pawlusiński 2003). Samospráva obce Bílá, díky podpoře rozvoje cestovního ruchu a rozšiřující se spolupráci s mnoha místními aktéry, má zajištěn ziskový rozpočet. Obce, které ve svém rozvoji podpořily modernizaci rekreačních středisek, patří dnes k turisticky nejnavštěvovanějším. Inovace turistické, dopravní a technické infrastruktury se stávají novým impulsem k dynamickému rozvoji cestovního ruchu a k růstu konkurenceschopnosti venkovských obcí. V souvislosti s tím v nich dochází $\mathrm{k}$ jejich ekonomické stabilizaci i k pozitivním demografickým změnám. Tyto aspekty cestovního ruchu v horských regionech Evropy hodnotili Stalder, Wyder (2002) nebo Kurek (2004). Na příkladu venkovských oblastí a horských středisek v Alpách a Karpatech poukazují na značné disparity v jejich rozvoji. Na základě statistických ukazatelů dokládají, že ve vybraných horských oblastech Švýcarska i Polska byl ve 2. polovině 20. století cestovní ruch klíčovým faktorem pozitivních demografických změn, růstu počtu obyvatel horských obcí (v některých př́padech až o desítky procent, jako například v kantonech Wallis, Graubünden a dalších) i hlavním faktorem celkového hospodářského rozvoje regionů, a to zejména v důsledku dynamického rozvoje specifických služeb cestovního ruchu. Podobné trendy byly potvrzeny také v zájmovém území Beskyd. V obci Bílá se v důsledku rozvoje cestovního ruchu změnil charakter, dříve zaostávající, migračně ztrátové obce. Počet obyvatel této malé obce, lokalizované v periferním území, se stabilizoval. V obci (s cca 145 ekonomicky aktivními obyvateli) se v posledních letech zvýšil počet pracovních míst v různých službách, vázaných na cestovní ruch, na téměř 300 . Rozvoj podnikatelských a pracovních příležitostí vyvolal nárůst dojížd'ky za prací do obce z širokého zázemí. Obec Bílá tak změnila výrazně svou image a zařadila se $\mathrm{k}$ ojedinělým venkovským obcím s širším rozvojovým potenciálem $\mathrm{v}$ rámci periferních př́hraničních regionů Česka.

K diskutovaným tématům dopadů cestovního ruchu patří i environmentální dopady, které zmiňují v odborné literatuře např́klad Holden (2000), Hall, Page (1999) a další. Rozvoj turistických středisek, sportovní a rekreační infrastruktury je však v současnosti nemožný bez procesu posuzování vlivu staveb a jejich provozování na životní prostředí (proces EIA), který má tyto dopady eliminovat. Přesto, zvláště v chráněných územích, je často ochranáři a ekologickými aktivisty zdůrazňován negativní dopad různých zařízení a sportovně-rekreačních aktivit na př́rodní prostředí. Aktivisté se mnohdy snaží zamezit jakékoliv modernizaci středisek.V př́ipadě lyžařských areálů a jejich vlivů na př́rodní složky krajiny jsou posuzovány vlivy ohrožení ekologické stability a biodiverzity, poškozování lesních a lučních biotopů, plošná či liniová eroze $\mathrm{v}$ trasách sjezdovek, snowboardparků, cyklostezek ale také nebezpečí degradace půd, změny hydrologických poměrů nebo eutrofizace vod vlivem umělého zasněžování či večerní světelné zatížení areálů s negativními vlivy na zvěř, na které upozorn̆ují ve studiích Holden (2000) nebo Flousek, Harčarik (2009). O těchto vlivech je na území Beskyd dosud velmi málo poznatků. I když se mohou lokálně projevit, jejich rozsah, vzhledem k malé rozloze lyžařských areálů, je vcelku zanedbatelný v porovnání s jinými negativními vlivy. V oblasti Beskyd se nachází přes 40 lyžařských areálů (většina je lokalizována mimo CHKO Beskydy), ale celková délka využívaných sjezdovek dosahuje pouhých $20 \mathrm{~km}$. Při sportovně-rekreační infrastruktury v Beskydech dosud zásadním způsobem malé šířce sjezdovek (v lesních průsecích v průměru kolem 30 metrů), činí celková rozloha lyžařských svahů přibližně $0,6 \mathrm{~km}^{2}$, což představuje zanedbatelný zlomek z celkové rozlohy CHKO Beskydy. Modernizovaných, uměle zasněžovaných a intenzivně využívaných lyžařských areálů je v zájmovém území jen necelá pětina. Dopady provozu beskydských areálů (po dobu průměrně tří měsíců v roce) jsou tak relativně malé v porovnání s velkými rekreačními středisky, např́klad v Demänovské dolině - Jasné, které sledovali Rakytová, Tomčíková, Krtička 2015). Inovace v zájmovém území nepoznamenaly 
horskou krajinu a biotopy, jako např́klad v exponovaných lokalitách Nízkých Tater, kde uvedené vlivy hodnotili Krtička, Rakytová, Tomčíková (2018). Současně v důsledku ukončení provozu v řadě zastaralých areálů došlo již $\mathrm{k}$ jejich zarůstání. Tyto změny jsou registrovány např́klad na Ondřejníku, Ostravici, Lysé hoře, na Javorovém vrchu, Pustevnách a jinde, kde se o dřivější lyžařské terény již několik let nikdo nestará, mnohdy z důvodů nevyjasněných vlastnických vztahů nebo střetů zájmů, které často znemožnily realizaci rozvojových projektů modernizace středisek. Konfliktní situace, vyplývající ze zcela protichůdných zájmů lokálního rozvoje a ochrany krajiny, jsou zde velmi časté. Ekologičtí aktivisté mnohdy svými nekompromisními prŕstupy zmařili realizaci rozvojových projektů ve venkovských obcích a zabránili jakýmkoliv inovacím či změnám proti původnímu stavu. Představují tak často bariéru v lokálním a regionálním rozvoji. V obci Bílá byly tyto konflikty díky dobré kooperaci lokálních aktérů uspokojivě vyřešeny, avšak v jiných obcích zůstávají tyto střety zájmů problémem v jejich rozvoji, naprríklad v lokalitách Nýdku, Oldřichovic, Trojanovic-Pusteven, Krásné, Ostravice-Lysé hory (Gabzdyl 2018). V modernizovaných střediscích však přibývají problémy jiného druhu, zvláště problémy bezpečnosti na lyžařských svazích. Ty jsou sice částečně eliminovány zaváděnými bezpečnostními opatřeními a pravidelnou úpravou lyžařských tratí, na druhé straně ale rostoucí zájem lyžařů a snowboardistů, zejména o kvalitní střediska, s dokonale upravenými sjezdovkami, zvyšuji jejich zatíženost a tím i nebezpečí úrazů, plynoucích z přeplněnosti svahů, z rychlejší, často nekontrolované a neohleduplné jízdy po vyhlazených či zledovatělých svazích. Roste tím počet vážných úrazů ze střetů lyžařu a snowboardistů, zejména na úzkých sjezdovkách, které dosud v oblasti Beskyd převažují. Nevyhovující šířkové parametry sjezdovek v lesních průsecích toto nebezpečí mimořádně zvyšují, proto jsou záměry na rozšiřrení zvláště př́ikrých a členitých svahů na bezpečnější šiřřu v těchto areálech opodstatněné. K diskutovaným environmentálním dopadům patří i dopady rostoucího dopravního zatížení území. V Beskydech dochází v důsledku nárůstu intenzity silniční dopravy ke zvýšené koncentraci prašných částic a dalších škodlivin $\mathrm{v}$ ovzduší a k prokazatelnému poškození lesních porostů, zvláště podél hlavní silniční komunikace I/56. Ačkoliv v zájmovém území nejsou lokalizovány měřící stanice znečištění ovzduší, důsledky rostoucí, zvláště těžké kamionové dopravy chráněnou oblastí, jsou na lesních porostech zřetelné. Současně zde eskalují problémy bezpečnosti provozu na jediné silniční komunikaci, procházející rekreační obcí. Kromě imisního zatížení území dochází zde rovněž k poškození smrkových biotopů kůrovcem, mimo jiné i v důsledku nevhodných postupů při velkoplošné těžbě dřeva. Evidovaná rozloha poškozených porostů kůrovcem a objem zničených smrkových monokultur byl v letech 2010 - 2017 v Moravskoslezském regionu v rámci Česka nejvyšší (Knížek, Liška 2018, Hlásný, Holuša, Turčáni 2018).

\section{Závěr}

Případová studie přispěla $\mathrm{k}$ rožšíření dosavadních poznatků o současných proměnách venkovských obcí. Ačkoliv je turistický potenciál horských obcí v Beskydech využíván ve větší míře už od 60. let minulého století, v posledních letech jen některé obce reagují na měnící se požadavky a nároky turistů na kvalitní, širokou a komplexní vybavenost rekreačních stř̌edisek a na aktuální trendy růstu konkurenceschopnosti a atraktivity obcí, spojené s pestrou produktovou nabídkou středisek, zaměřenou na všechny segmenty návštěvníků. Obec Bílá je v současnosti zdařilým př́ikladem úspěšně se rozvíjející obce, s řadou inovací, jakož i obce s atraktivní nabídkou rekreačních, sportovních a relaxačních produktů, které jsou žádaným doplňkem k tradičním zimním sportům a turistice. Dřívější sezónní podniková rekreační stř̌ediska se transformovala na komerční, celoročně využivaná střediska. Po období stagnace volného cestovního ruchu v etapě socialistického vývoje dnes managementy rekreačních zařízení stále aktivněji spolupracují mezi sebou a nabízejí škálu společných produktů a doprovodných služeb, vč. různých zvýhodněných balíčků, prričemž stále větší roli v zaměření jejich nabídky mají rodiny s dětmi. 
Z hlediska prŕnosů, studie prohloubila poznatky o transformaci dříve zaostávajícího periferního regionu. Venkovské obce, které v 70. a 80 . letech byly řazeny mezi nestřediskové obce, bez možností intenzivnějšího hospodářského rozvoje, se v současné době rychle mění. V některých horských lokalitách byly sice v tomto období rozvíjeny formy vázané nebo individuální rekreace na chatách, avšak teprve od 90 . let, v rámci transformačních procesů, došlo k zásadním změnám ve využití turistického potenciálu obcí a k rozvoji forem volného cestovního ruchu, který byl do té doby značně omezen. Studie prokázala, že v lokálním rozvoji, má dnes klíčový význam spolupráce všech místních aktérů. Díky kooperaci soukromého podnikatelského sektoru a veřejného sektoru se podařilo výrazně změnit atraktivitu obce. Akcent na rozvoj turistické funkce přinesl horským obcím řadu pozitivních efektů. Periferní poloha zájmového území byla v minulosti bariérou, $\mathrm{v}$ současnosti je příležitostí $\mathrm{k}$ dalšímu lokálnímu a regionálnímu rozvoji. Oživení kontaktů příhraničních regionů Česka, Slovenska a Polska a mnohostranná spolupráce v rámci euroregionů Beskydy a Těšínské Slezsko, mj. v oblasti rozvoje cestovního ruchu, infrastruktury a kooperace mezi obcemi jsou předpokladem úspěšného rozvoje a růstu atraktivity venkovských obcí i rostoucího zájmu domácích a zahraničních turistů o modernizovaná střediska. Předmětem dalšího výzkumu, který bude navazovat na tuto studii, bude porovnání sociálně-ekonomického rozvoje a zhodnocení změn v př́hraničních regionech v polské a slovenské části Beskyd, a to ve spolupráci s partnerskými vysokými školami a dalšími zainteresovanými institucemi $\mathrm{v}$ obou zemích s cílem využití a uplatnění příkladů dobré praxe v lokálním a regionálním rozvoji. Získané výsledky mohou být cenným podkladem při zpracování strategií rozvoje periferních regionů a projektů rozvoje cestovního ruchu ve venkovských mikroregionech a obcích.

\section{Literatura}

BERNARD, J., KOSTELECKÝ, T., ILLNER, M., VOBECKÁ, J. 2011: Samospráva venkovských obcí a místní rozvoj. Praha (SLON).

ČSÚ 2018: Bilance počtu obyvatel v obcích Moravskoslezského kraje. Dostupné na: https://www.czso.cz/documents/11288/17833687/obce_MSK_2018.pdf/65406ccc-8e054c6d-a311-6eb9a8e30c37?version=1.1

FARRELL, G., THIRION, S. 2000: Economic Competitiveness of Rural Areas. Creating a Territorial Development Strategy in the Light of the LEADER Experience, Rural Innovation Dossier, 6, Brussels (LEADER European Observatory).

FIALOVÁ, D. 2014: Druhé bydlení v Česku: včera, dnes a zítra. In Blažková, T., Fialová, D., Matoušek, V. eds. Individuální a masová rekreace v okolí velkých industriálních měst v 19. - 21. století. Praha (Togga, s.r.o.), 43-62.

FLOUSEK, J., HARČARIK, J. 2009: Sjezdové lyžování a ochrana přírody. Ochrana prírody, 6, Praha (Ministerstvo životního prostředí ČR).

GABZDYL, J. 2018: Konec snů o lanovce na Lysou horu, kraj dává přednost Čantoryji a Pradědu. iDNES.cz. [online] [2018-08-17]. Dostupné na: https://www.idnes.cz/ostrava/zpravy/lanovkalysa-hora-lanovky-praded-nydek.A170831_348990ostrava-zpravy_jog

GEORGE, W. E, MAIR, H., REID, D. 2009: Rural Tourism Development. Localism and Cultural Change. Bristol, Buffalo, Toronto (Channel View Publications).

HALL, C. M., JENKINS, J. M. 1995: Tourism and Public Policy. London (Routledge).

HALL, C. M., PAGE, S. J. 1999: The Geography of Tourism and Recreation: Environment, Place and Space. London (Routledge).

HAVRLANT, J. 2000: Beskydy - Transformace pohraniční oblasti cestovního ruchu. Spisy prací Přírodovědecké fakulty Ostravské univerzity, 128, Ostrava (Př́rodovědecká fakulta, Ostravská univerzita). 
HAVRLANT, J. 2006: Modernizace turistické infrastruktury v Euroregionech Beskydy a Těšínské Slezsko. Sborník z XXI. Sjezdu ČGS, Česká geografie v evropském prostoru. České Budějovice (Jihočeská univerzita), 73-80.

HAVRLANT, M. 1977: Zázemí ostravské průmyslové oblasti, jeho funkce a možnosti využití pro rekreační účely. Spisy Pedagogické fakulty, 36, Ostrava (Pedagogická fakulta).

HLÁSNY, T., HOLUŠA, J., TURČÁNI, M. 2018: Očekávaná změna počtu generací lýkožrouta smrkového za rok $v$ prírodních lesních oblastech Moravskoslezské Beskydy a Podbeskydská pahorkatina v období 2021-2050 oproti období 1961-1990 v podmínkách změny klimatu. Jíloviště (Výzkumný ústav lesního hospodářství a myslivosti).

HOLDEN, A. 2000: Environment and Tourism. London (Routledge).

HORÁKOVÁ, H., FIALOVÁ, D. 2014: Transformace venkova - Turismus jako forma rozvoje. Plzeň (Čeněk s.r.o.).

HORNER, S., SWARBROOKE, J. 2003: Cestovní ruch, ubytování a stravování, využití volného času. Aplikovaný marketing služeb. Praha (Grada Publishing a.s.).

ILBERY, B. ed. 1998: The Geography of Rural Social Change. Harlow (Longman).

KALABISOVÁ, J., STUDNIČKA, P., PLZÁKOVÁ, L., TINKOVÁ, V. 2012: Měrení efektů cestovního ruchu v obci Lipno nad Vltavou. Praha (Vysoká škola hotelová).

KNÍŽEK, M., LIŠKA J. 2018: Výskyt lesních škodlivých činitelů v roce 2017 a jejich očekávaný stav v roce 2018. Zpravodaj ochrany lesa, 21, Jíloviště (Výzkumný ústav lesního hospodářství a myslivosti).

KRTIČKA, L., RAKYTOVÁ, I., TOMČÍKOVÁ, I. 2018: Development versus conservation: evaluation of landscape structure changes in Demänovská Valley, Slovakia. Journal of Mountain Science, 6 (15), 1153-1170. DOI: https://doi.org/10.1007/s11629-018-4870-0

KULLA, M. 2011: Vybrané aspekty cestovného ruchu na Zemplínskej Šírave. Geographia Cassoviensis, V (1), Košice (Prírodovedecká fakulta, Univerzita P. J. Šafárika), 73-78.

KUREK, W. 2004: Turystyka na obszarach górskich Europy. Kraków (Instytut geografii i Gospodarki Przestrzennej, Uniwersytet Jagielloński).

MARIOT, P. 1983: Geografia cestovného ruchu. Bratislava (SAV, Veda).

MIKA, M., PAWLUSIŃSKI, R. 2003: Opportunities for cooperation of local governments for the development of tourism in Poland. Prace Geograficzne UJ, 111, Kraków (Uniwersytet Jagielloński), 201-215.

MINISTERSTVO FINANCÍ ČR 2018: Výkazy pro hodnocení plnění rozpočtu ÚSC, obec Bílá 1996-2018. Praha (Ministerstvo financí ČR).

MÍSTOPISNÝ PRU゚VODCE PO ČESKÉ REPUBLICE 2018: Počet obyvatel obce Bílá. Dostupné na: https://www.mistopisy.cz/ pruvodce/obec/7761/bila/pocet-obyvatel/

OBEC BÍLÁ 2018: Oficiální stránky obce, ubytování. Dostupné na: http://www.obecbila.cz/volny-cas/ubytovani/

PÁSKOVÁ, M., ZELENKA, J. 2002: Cestovní ruch - výkladový slovník. Praha (Ministerstvo pro místní rozvoj ČR).

PERLÍN, R., KUČERA, Z., KUČEROVÁ, S. 2010: Typologie venkovského prostoru Česka, Geografie, 115 (2), Praha (Př́rodovědecká fakulta, Univerzita Karlova), 161-187.

PIETRZYK SOKULSKA, E. 2006: Typologia gmin. In Warszyńska J. ed. Turystyka zrównowaźona na obszarze Beskidów Zachodnich; Studium uwarunkowań i barier rozwoju. Kraków (IGSMiE PAN), 149-175.

RAKYTOVÁ, I., TOMČÍKOVÁ, I., KRTIČKA, L. 2015: Zmena štruktúry krajiny v priestore zat'aženom cestovným ruchom na príkladě rekreačného strediska Demänovská dolina Jasná. Acta Geographica Universitatis Comenianae, 59 (1), 83-96. 
RUCKI, D. 2011: Marketingová strategie rozvoje cestovního ruchu turistické oblasti BeskydyValašsko. Ostrava (DHV CR, s.r.o.).

RUDA, A. 2008: Hodnocení vlivu cestovního ruchu na krajiny Nízého Jeseníku metodami GIS - disertační práce. Ostrava (Př́rodovědecká fakulta, Ostravská univerzita).

SKI AREÁL BÍLÁ. 2018: Interní dokumenty 1998-2018. Bílá (Ski Bílá Služby s.r.o.).

STALDER, U., WYDER, J. 2002: Implementation of innovative structures for a sustainable development in mountain areas - evidences from Switzerland, ISDEMA Project. Paper to the seminar. Thessaloniki.

ŠIMOŇÁKOVÁ, P., DIVÁKOVÁ, D. 2008: Sociodemografická analýza regionu Frýdlantsko - Beskydy. Ostrava (Institut komunitního rozvoje).

ŠPRINCOVÁ, S. 1969: Geografie cestovního ruchu v Jeseníkách. Acta Universitatis Palackianae Olomucensis, Geographica, 23, Olomouc (Univerzita Palackého).

VANÍČEK, J. 2006: Atraktivita vybraných obcí ČR pro turisty a výletníky. COT business, 7 , Praha, 54-56.

VELLAS, F. 2011: The indirect impact of Tourism. An Economic Analysis. Paris (Tourism Ministers).

VYSTOUPIL, J., HOLEŠINSKÁ, A., KUNC, J. et al. 2006: Atlas cestovního ruchu České republiky. Brno (Ekonomicko-správní fakulta, Masarykova univerzita).

VYSTOUPIL, J., ŠAUER, M. 2006: Základy cestovního ruchu. Brno (Ekonomicko-správní fakulta, Masarykova univerzita).

\section{Adresa autora}

doc. RNDr. Jan Havrlant, CSc.

Katedra sociální geografie a regionálního rozvoje

Ostravská univerzita, Př́rodovědecká fakulta

Chittussiho 10, 71000 Ostrava

Česká republika

jan.havrlant@osu.cz 